\title{
Strong sensitivity of the isotopic composition of methane to the plausible range of tropospheric chlorine
}

\author{
Sarah A. Strode ${ }^{1,2}$, James S. Wang ${ }^{1,2, a}$, Michael Manyin ${ }^{2,3}$, Bryan Duncan ${ }^{2}$, Ryan Hossaini ${ }^{4}$ Christoph A. Keller $^{1,2}$, \\ Sylvia E. Michel ${ }^{5}$, and James W. C. White ${ }^{5}$ \\ ${ }^{1}$ Universities Space Research Association, Columbia, MD, USA \\ ${ }^{2}$ NASA Goddard Space Flight Center, Greenbelt, MD, USA \\ ${ }^{3}$ Science Systems and Applications Inc. (SSAI), Lanham, MD, USA \\ ${ }^{4}$ Lancaster Environment Centre, Lancaster University, Lancaster, UK \\ ${ }^{5}$ Institute of Arctic and Alpine Research, University of Colorado, Boulder, Boulder, CO, USA \\ ${ }^{a}$ now at: Institute for Advanced Sustainability Studies, Potsdam, Germany
}

Correspondence: Sarah A. Strode (sarah.a.strode@nasa.gov)

Received: 5 March 2020 - Discussion started: 6 April 2020

Revised: 21 May 2020 - Accepted: 6 June 2020 - Published: 17 July 2020

\begin{abstract}
The ${ }^{13} \mathrm{C}$ isotopic ratio of methane, $\delta^{13} \mathrm{C}$ of $\mathrm{CH}_{4}$, provides additional constraints on the $\mathrm{CH}_{4}$ budget to complement the constraints from $\mathrm{CH}_{4}$ observations. The interpretation of $\delta^{13} \mathrm{C}$ observations is complicated, however, by uncertainties in the methane sink. The reaction of $\mathrm{CH}_{4}$ with $\mathrm{Cl}$ is highly fractionating, increasing the relative abundance of ${ }^{13} \mathrm{CH}_{4}$, but there is currently no consensus on the strength of the tropospheric $\mathrm{Cl}$ sink. Global model simulations of halogen chemistry differ strongly from one another in terms of both the magnitude of tropospheric $\mathrm{Cl}$ and its geographic distribution. This study explores the impact of the intermodel diversity in $\mathrm{Cl}$ fields on the simulated $\delta^{13} \mathrm{C}$ of $\mathrm{CH}_{4}$. We use a set of GEOS global model simulations with different predicted $\mathrm{Cl}$ fields to test the sensitivity of the $\delta^{13} \mathrm{C}$ of $\mathrm{CH}_{4}$ to the diversity of $\mathrm{Cl}$ output from chemical transport models. We find that $\delta^{13} \mathrm{C}$ is highly sensitive to both the amount and geographic distribution of $\mathrm{Cl}$. Simulations with $\mathrm{Cl}$ providing $0.28 \%$ or $0.66 \%$ of the total $\mathrm{CH}_{4}$ loss bracket the $\delta^{13} \mathrm{C} \mathrm{ob-}$ servations for a fixed set of emissions. Thus, even when $\mathrm{Cl}$ provides only a small fraction of the total $\mathrm{CH}_{4}$ loss and has a small impact on total $\mathrm{CH}_{4}$, it provides a strong lever on $\delta^{13} \mathrm{C}$. Consequently, it is possible to achieve a good representation of total $\mathrm{CH}_{4}$ using widely different $\mathrm{Cl}$ concentrations, but the partitioning of the $\mathrm{CH}_{4}$ loss between the $\mathrm{OH}$ and $\mathrm{Cl}$ reactions leads to strong differences in isotopic composition depending on which model's $\mathrm{Cl}$ field is used. Comparing multiple simulations, we find that altering the tropospheric $\mathrm{Cl}$ field leads to
\end{abstract}

approximately a $0.5 \%$ increase in $\delta^{13} \mathrm{CH}_{4}$ for each percent increase in how much $\mathrm{CH}_{4}$ is oxidized by $\mathrm{Cl}$. The geographic distribution and seasonal cycle of $\mathrm{Cl}$ also impacts the hemispheric gradient and seasonal cycle of $\delta^{13} \mathrm{C}$. The large effect of $\mathrm{Cl}$ on $\delta^{13} \mathrm{C}$ compared to total $\mathrm{CH}_{4}$ broadens the range of $\mathrm{CH}_{4}$ source mixtures that can be reconciled with $\delta^{13} \mathrm{C}$ observations. Stronger constraints on tropospheric $\mathrm{Cl}$ are necessary to improve estimates of $\mathrm{CH}_{4}$ sources from $\delta^{13} \mathrm{Cob}$ servations.

\section{Introduction}

The global budget of methane is of great interest due to methane's role as a greenhouse gas, ozone precursor, and sink of the hydroxyl radical. Despite extensive study, major uncertainties in the methane budget remain, with topdown and bottom-up estimates often yielding different results (Kirschke et al., 2013; Saunois et al., 2016, 2017, and references therein) for the strength of specific source types. Furthermore, the resumed increase of methane concentrations beginning in 2007 (Dlugokencky et al., 2009; Rigby et al., 2008) can be explained by multiple hypotheses including an increase in fossil fuel emissions (Turner et al., 2016; Thompson et al., 2015; Hausmann et al., 2016), an increase in fossil fuel emissions combined with a decrease in biomass burning (Worden et al., 2017), an increase in bio- 
genic sources (Schaefer et al., 2016; Nisbet et al., 2016), or a decrease in hydroxyl concentrations (Turner et al., 2017; Rigby et al., 2017). Variations in hydroxyl concentrations may also be important for the decrease in methane growth from 1999 to 2006 (McNorton et al., 2016).

Observations and modeling of methane's carbon isotopes provide additional information on methane sources since individual sources differ in their ${ }^{13} \mathrm{C}$ to ${ }^{12} \mathrm{C}$ ratio $\left(\delta^{13} \mathrm{C}\right)$. Isotopic information can be used to better constrain methane sources (e.g., Thompson et al., 2015; Mikaloff Fletcher et al., 2004a, b) and infer how the source mixture changed over glacial (e.g., Hopcroft et al., 2018; Fischer et al., 2008; Bock et al., 2017), millennial (e.g., Ferretti et al., 2005; Houweling et al., 2008), and decadal timescales (e.g., Nisbet et al., 2016; Schaefer et al., 2016; Kai et al., 2011; Schwietzke et al., 2016; Thompson et al., 2018). However, there are considerable uncertainties in the processes that control methane's isotopic composition that may confound source apportionment studies. Many modeling studies use a single value for the isotopic ratio of each source, while in reality sources such as wetlands, biomass burning, and natural gas show large regional or environment-dependent variations in their isotopic signature (Ganesan et al., 2018; Brownlow et al., 2017; Dlugokencky et al., 2011; Schwietzke et al., 2016; Sherwood et al., 2017).

The isotopic composition of atmospheric methane is also sensitive to methane's sinks. Reaction with $\mathrm{OH}$, the principal loss for atmospheric methane, has a kinetic isotope effect (KIE) of $-5.4 \%$ \% $\left(\alpha=k_{13} / k_{12}=0.9946\right)$ to $-3.9 \%$ o $(\alpha=$ 0.9961) (Saueressig et al., 2001; Cantrell et al., 1990) and contributes to the interhemispheric gradient of $\delta^{13} \mathrm{C}$ (Quay et al., 1991). Mass balance (Lassey et al., 2007) and observations of the seasonal cycle of $\delta^{13} \mathrm{C}$ versus methane concentration, however, suggest larger apparent KIE values, which may indicate a role for methane oxidation by chlorine $(\mathrm{Cl})$ in the marine boundary layer (MBL) (Allan et al., 2001, 2007) since $\mathrm{Cl}$ has a KIE of $-61.9 \%$ o $(\alpha=0.938)$ at $297 \mathrm{~K}$ (Saueressig et al., 1995). Inclusion of the MBL Cl sink alters the source mixture inferred from inverse modeling of $\delta^{13} \mathrm{CH}_{4}$ (Rice et al., 2016). Nisbet et al. (2019) point out that interannual variability in the $\mathrm{CH}_{4} \mathrm{Cl}$ sink could explain some of the variability of $\delta^{13} \mathrm{C}$. $\mathrm{Cl}$ is also an important methane sink in the stratosphere, and the impact of this sink on surface $\delta^{13} \mathrm{C}$ is a source of uncertainty in modeling $\delta^{13} \mathrm{C}$ (Ghosh et al., 2015). Reaction with stratospheric $\mathrm{Cl}$ contributes approximately $0.23 \%$ to the $\delta^{13} \mathrm{C}$ of surface methane and makes a small contribution to the observed trend in surface $\delta^{13} \mathrm{C}$ over the last century (Wang et al., 2002).

The global concentration of $\mathrm{Cl}$ in the MBL and its role in the methane budget is still uncertain. $\mathrm{Cl}$ concentrations are highly variable and not well constrained by direct observations. Modeling work by Hossaini et al. (2016) and Sherwen et al. (2016) suggests that chlorine provides $2 \%-2.5 \%$ of tropospheric methane oxidation. This agrees well with estimates based on the isotopic fractionation, which also sug- gest $\mathrm{Cl}$ provides several percent of the total sink (Allan et al., 2007; Platt et al., 2004). However, Gromov et al. (2018) suggest that these are overestimates as values over $1 \%$ are inconsistent with the $\delta^{13} \mathrm{C}$ of $\mathrm{CO}$, which is a product of $\mathrm{CH}_{4}$ oxidation. The recent modeling study of Wang et al. (2019) also suggests a value of $1 \%$. There is thus considerable uncertainty in the role of chlorine in the budget and isotopic composition of methane.

Here, we investigate the sensitivity of $\delta^{13} \mathrm{C}$ of $\mathrm{CH}_{4}$ to intermodel diversity in tropospheric chlorine concentrations to better quantify how much uncertainty in the interpretation of $\delta^{13} \mathrm{C}$ is imposed by the uncertainty in $\mathrm{Cl}$. Section 2 describes the modeling framework. We present results for total $\mathrm{CH}_{4}$ and its isotopic composition compared to surface observations in Sect. 3 and discuss the implications for the global $\mathrm{CH}_{4}$ budget in Sect. 4.

\section{Methods}

\subsection{Model description}

We simulate atmospheric methane with the Goddard Earth Observing System (GEOS) global earth system model (Molod et al., 2015; Nielsen et al., 2017). The model has 72 vertical levels extending from the surface to $1 \mathrm{~Pa}$. We conduct simulations at $\mathrm{C} 90$ resolution on the cubed sphere, which corresponds to approximately $100 \mathrm{~km}$ horizontal resolution. The simulations' meteorology is constrained to the MERRA-2 reanalysis (Gelaro et al., 2017) using a "replay" method (Orbe et al., 2017). The GEOS replay agrees well with the tropospheric mean age of the Global Modeling Initiative (GMI) chemistry and transport model (CTM) (Orbe et al., 2017), which shows reasonable agreement with the age derived from $\mathrm{SF}_{6}$ observations, albeit with an old bias in the Southern Hemisphere (Waugh et al., 2013). We thus expect the simulated interhemispheric transport time to be reasonable.

The GEOS $\mathrm{CH}_{4}$ simulation can be interactively coupled to $\mathrm{CO}$ and $\mathrm{OH}$ (Elshorbany et al., 2016) or run independently with prescribed $\mathrm{OH}$ fields. We take the latter approach in this study, since this approach is able to capture many of the observed variations in atmospheric methane (Elshorbany et al., 2016). We prescribe the OH field following (Spivakovsky et al., 2000) but modify the $\mathrm{OH}$ to be approximately $20 \%$ higher in the Northern Hemisphere than the Southern Hemisphere, consistent with the $\mathrm{OH}$ field produced by many global atmospheric chemistry models (Naik et al., 2013; Strode et al., 2015). This modification is designed to make our results more applicable to understanding the impacts of intermodel differences in $\mathrm{Cl}$, since it makes our $\mathrm{OH}$ distribution more consistent with that produced by many chemistry-climate models (CCMs). The $\mathrm{OH}$ field varies monthly but repeats every year. We also include stratospheric losses for $\mathrm{CH}_{4}$ from reaction with $\mathrm{OH}, \mathrm{Cl}$, and 
$\mathrm{O}^{1} \mathrm{D}$. These fields are prescribed from output of the GMI CTM (https://gmi.gsfc.nasa.gov, last access: 13 July 2020) (Strahan et al., 2007; Duncan et al., 2007).

We implement the $\mathrm{CH}_{4}$ isotopes in GEOS by separately simulating ${ }^{13} \mathrm{CH}_{4}$ and ${ }^{12} \mathrm{CH}_{4}$ tracers. We then calculate total $\mathrm{CH}_{4}$ as the sum of the two carbon isotopologues and calculate $\delta^{13} \mathrm{C}_{\text {of }} \mathrm{CH}_{4}$ in per mil using the standard definition:

$\delta^{13} \mathrm{C}-\mathrm{CH}_{4}(\% o)=\left(\left[{ }^{13} \mathrm{CH}_{4}\right] /\left[{ }^{12} \mathrm{CH}_{4}\right] / R_{\mathrm{std}}-1\right) \cdot 1000$,

where $R_{\text {std }}=0.0112372$ is the Peedee belemnite (PDB) isotopic standard (Craig, 1957). We partition each emission source into ${ }^{12} \mathrm{CH}_{4}$ and ${ }^{13} \mathrm{CH}_{4}$ emissions according to a source-specific $\delta^{13} \mathrm{C}$ value from the literature, provided in Table 1 . We use the Craig (1957) $R_{\text {std }}$ value to partition the sources since it is cited in the literature used in Table 1 (Houweling et al., 2000; Lassey, 2007), and so for consistency we use the same value in Eq. (1) to calculate the simulated $\delta^{13} \mathrm{C}$ of the $\mathrm{CH}_{4}$ concentrations. We note, however, that the Global Monitoring Division (GMD) observations now use a slightly different standard, the Vienna PDB (VPDB) value of 0.011183 (Zhang and $\mathrm{Li}, 1990$ ). A sensitivity study (not shown) confirms that the choice $R_{\text {std }}$ has little effect on our results as long as the same value is used for the source partitioning as for the calculation of $\delta^{13} \mathrm{C}^{1} \mathrm{CH}_{4}$ from simulated $\left[{ }^{13} \mathrm{CH}_{4}\right]$ and $\left[{ }^{12} \mathrm{CH}_{4}\right]$.

The reaction rates for $\mathrm{CH}_{4}+\mathrm{OH}, \mathrm{CH}_{4}+\mathrm{Cl}$, and $\mathrm{CH}_{4}+\mathrm{O}^{1} \mathrm{D}$ differ between the ${ }^{12} \mathrm{CH}_{4}$ and ${ }^{13} \mathrm{CH}_{4}$ simulations to account for the kinetic isotope effect (KIE). In particular, we assume $\alpha$ values of 0.987 and 0.938 for $\mathrm{CH}_{4}+\mathrm{O}^{1} \mathrm{D}$ and $\mathrm{CH}_{4}+\mathrm{Cl}$, respectively (Saueressig et al., 1995, 2001). Our standard simulation uses $\alpha_{\mathrm{OH}}=0.9946$ (Cantrell et al., 1990).

Methane from different sources is tracked individually using a "tagged tracer" approach, which allows us to simulate the spatial footprint of $\mathrm{CH}_{4}$ and $\delta^{13} \mathrm{C}_{-} \mathrm{CH}_{4}$ from individual sources. The soil sink is applied to each tracer as a fraction of its source, modified to account for faster loss of ${ }^{12} \mathrm{CH}_{4}$ to soil compared to ${ }^{13} \mathrm{CH}_{4}\left(\alpha_{\text {soil }}=0.978\right)$ (Tyler et al., 1994). Figure S1 in the Supplement shows the July $2004 \mathrm{CH}_{4}$ and $\delta^{13} \mathrm{C}^{-} \mathrm{CH}_{4}$ footprints of the biomass burning, wetland, and coal plus other geologic $\mathrm{CH}_{4}$ sources from the tagged tracers to illustrate the tagged tracer approach. We note that the $\delta^{13} \mathrm{C}$ values of the surface methane from each source is heavier (less negative) than the emission value for that source (Table 1), especially in regions far from the source, because of the fractionating effects of the sinks. Figure S2 shows the corresponding footprints for January.

\subsection{Description of simulations}

We simulate the period from 1990 through 2004 and focus our analysis on 2004. We choose 2004 as our endpoint because it lies within the period when methane concentrations remained relatively flat, simplifying our analysis. Ending the simulations in 2004 also avoids much of the uncertainty about the causes of the resumed growth rate in recent years. The isotopic ratios of methane take longer to adjust to a perturbation than total methane (Tans, 1997). Since we wish to begin our simulations with a state that is as close as possible to "spun up", we choose the initial condition for each tagged tracer based on its present-day distribution and proportion of the total $\mathrm{CH}_{4}$ and scale it back to 1990 levels such that the total $\mathrm{CH}_{4}$ is consistent with the global mean $\mathrm{CH}_{4}$ from surface observations for 1990 . We then iteratively adjusted the ${ }^{12} \mathrm{C}$ - to ${ }^{13} \mathrm{C}_{-} \mathrm{CH}_{4}$ tracer ratios at the beginning of 1990 to yield a good match to global mean $\delta^{13} \mathrm{C}_{-} \mathrm{CH}_{4}$ observations for 1998 , when more $\delta^{13} \mathrm{C}_{-} \mathrm{CH}_{4}$ observations are available. The same initial condition is used for the standard and sensitivity simulations.

We use interannually varying emissions of $\mathrm{CH}_{4}$ from anthropogenic, biomass burning, and wetland sources. Emissions from anthropogenic sources such as oil and gas, energy production, industrial activities, and livestock come from the EDGAR version 4.2 inventory (European Commission, 2011). Biomass burning emissions come from the MACCity inventory (Granier et al., 2011). We treat forest fires as $\mathrm{C} 3$ burning and savannas as $\mathrm{C} 4$ burning for partitioning the biomass burning emissions between isotopologues. Wetland and rice emissions come from the Vegetation Integrative Simulator for Trace gases (VISIT) terrestrial ecosystem model (Ito and Inatomi, 2012), scaled by 0.69 and 0.895 , respectively, for consistency with the Transcom- $\mathrm{CH}_{4}$ study (Patra et al., 2011). Ocean (Houweling et al., 1999), termite (Fung et al., 1991), and mud volcano emissions (Etiope and Milkov, 2004) are also from the Transcom study (Patra et al., 2011) and have a seasonal cycle but no interannual variability. Initial tests with these emissions showed a substantial underestimate of the $\mathrm{CH}_{4}$ growth rate. Consequently, we scale up all the emissions by $10 \%$ for $1990-1998$ and by $6.8 \%$ for $1998-2004$. We find the resulting emissions lead to a good simulation of the time series of surface $\mathrm{CH}_{4}$ observations from the National Oceanic and Atmospheric Administration (NOAA) GMD (Dlugokencky et al., 2018), especially towards the end of the period (Fig. 1). The simulation has only a $0.1 \%$ mean bias compared to the observations for 2004.

Our standard simulation (SimStd) uses $\mathrm{Cl}$ from the GMI CTM for the tropospheric as well as stratospheric loss of $\mathrm{CH}_{4}$ by reaction with $\mathrm{Cl}$. Tropospheric $\mathrm{Cl}$ concentrations are small in GMI since it does not include very short lived species, and reaction with $\mathrm{Cl}$ represents only $0.28 \%$ of the total tropospheric $\mathrm{CH}_{4}$ loss. We also conduct several sensitivity simulations in which we alter the tropospheric and lower stratospheric $\mathrm{Cl}$ fields (Table 2). $\mathrm{Cl}$ is not altered above $56 \mathrm{hPa}$. Sensitivity simulation SimGC uses $\mathrm{Cl}$ from the GEOS-Chem chemistry module within GEOS (Long et al., 2015; Hu et al., 2018). GEOS-Chem v11-02f with fully coupled tropospheric and stratospheric chemistry was used for this simulation, with halogen chemistry as described in Sherwen et al. (2016). SimGC has higher values of tropospheric $\mathrm{Cl}$ than SimStd (Figs. 3, 4) and leads to $0.66 \%$ of the total $\mathrm{CH}_{4}$ loss 
Table 1. Emission source references, description of interannual variability (IAV), and $\delta^{13} \mathrm{C}$ values.

\begin{tabular}{|c|c|c|c|c|}
\hline Source & Reference & IAV & $\delta^{13} \mathrm{C}(\%)^{\mathrm{a}}$ & $\mathrm{CH}_{4}$ source $\left(\mathrm{Tg} \mathrm{yr}^{-1}\right)^{\mathrm{b}}$ \\
\hline Animals (enteric fermentation) & EDGAR & $\mathrm{Y}$ & -62 & 102 \\
\hline C3 biomass burning (forests) & MACCity & $\mathrm{Y}$ & -26 & 16 \\
\hline C4 biomass burning (savannas) & MACCity & $\mathrm{Y}$ & -15 & 10 \\
\hline Coal, energy, and industry & EDGAR & $\mathrm{Y}$ & -35 & 6 \\
\hline Geologic (oil/gas/noncoal fuels, volcanos) & EDGAR, Transcom & Y, except volcanos & -40 & 124 \\
\hline Waste (solid and animal waste, wastewater) & EDGAR & $\mathrm{Y}$ & -55 & 74 \\
\hline Ocean & Transcom & $\mathrm{N}$ & -59 & 8 \\
\hline Rice & VISIT model & $\mathrm{Y}$ & -63 & 44 \\
\hline Termites & Transcom & $\mathrm{N}$ & -57 & 22 \\
\hline Wetlands & VISIT model & $\mathrm{Y}$ & -60 & 149 \\
\hline
\end{tabular}

${ }^{\mathrm{a}} \delta^{13} \mathrm{C}$ values from Dlugokencky et al. (2011), Lassey et al. (2007), Monteil et al. (2011), Houweling et al. (2000), and references therein. ${ }^{\mathrm{b}}$ Values for 2004.
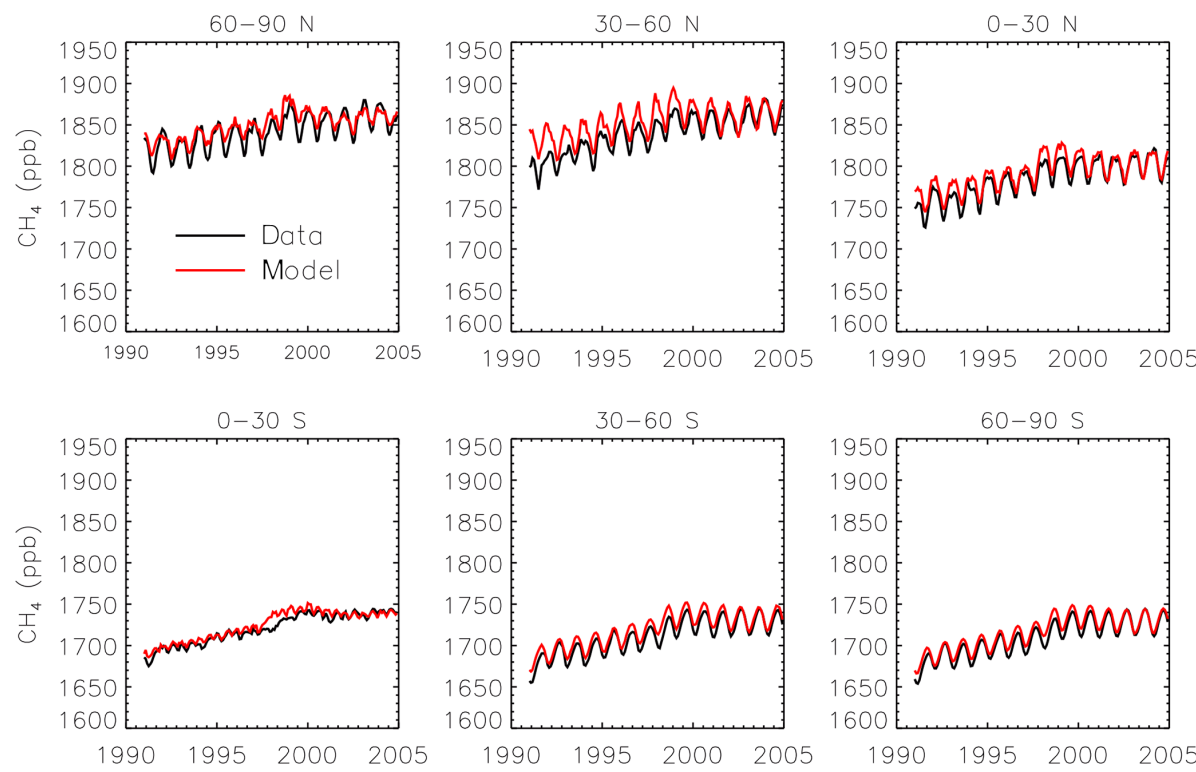

Figure 1. Monthly $\mathrm{CH}_{4}$ observations from the GMD network (black) and simulated surface concentrations from SimStd (red) averaged over latitude bands.

occurring via $\mathrm{Cl}$. Both SimStd and SimGC are thus below the $1 \%$ loss via $\mathrm{Cl}$ suggested by Gromov et al. (2018). We conduct a third sensitivity simulation, SimTom, which uses $\mathrm{Cl}$ from the TOMCAT model simulations that include chlorine sources from chlorocarbons (including very short lived substances), $\mathrm{HCl}$ from industry and biomass burning, and very short lived substances (Hossaini et al., 2016). This simulation leads to $\mathrm{Cl}$ accounting for $2.5 \%$ of tropospheric $\mathrm{CH}_{4}$ loss in our simulation. Finally, we conduct a fourth sensitivity simulation, SimMBL, which modifies the $\mathrm{Cl}$ over the oceans at altitudes below $900 \mathrm{hPa}$ (Fig. 2d) to reflect the marine boundary layer distribution suggested by Allan et al. (2007). This $\mathrm{Cl}$ field is described by the following equation:

$$
\begin{aligned}
\text { Cl_MBL } & =18 \times 10^{3} \text { atoms } \mathrm{cm}^{-3} \cdot(1+\tanh (3 \lambda) \\
& \cdot \sin (2 \pi \cdot(t-90) / 365))
\end{aligned},
$$

where $\lambda$ is latitude in radians and $t$ is the day of the year. Elsewhere SimMBL uses the $\mathrm{Cl}$ field from SimStd. This simulation has the highest percent of $\mathrm{CH}_{4}$ loss occurring via $\mathrm{Cl}$ : $3.9 \%$. If we consider the loss of methane throughout the atmosphere rather than just the troposphere, then the percent lost via $\mathrm{Cl}$ increases to $1.6 \%, 2.0 \%, 3.6 \%$, and $5.0 \%$ for SimStd, SimGC, SimTom, and SimMBL, respectively.

We designed the sensitivity experiments to alter the isotopic composition of $\mathrm{CH}_{4}$ without greatly affecting the total $\mathrm{CH}_{4}$. Consequently, we reduce the $\mathrm{OH}$ concentrations in the SimTom and SimMBL simulations by $2 \%$ and $4 \%$, respectively, relative to the SimStd $\mathrm{OH}$ to offset the effect of increasing $\mathrm{Cl}$. These changes are small compared to the uncertainty in global OH (Rigby et al., 2017). In addition, the SimTom and SimMBL simulations use $\alpha_{\mathrm{OH}}=0.9961$ (Saueressig et al., 2001) rather than $\alpha_{\mathrm{OH}}=0.9946$ (Cantrell et al., 
Table 2. Oxidants for the standard and sensitivity simulations.

\begin{tabular}{|c|c|c|c|c|}
\hline Simulation & {$[\mathrm{Cl}]_{\text {Trop }}{ }^{\mathrm{a}}\left(\right.$ molecules $\left.\mathrm{cm}^{-3}\right)$} & $\mathrm{Cl}$ model $^{\mathrm{b}}$ & $\mathrm{Cl}$ reference & $\mathrm{OH}_{\text {modification }}^{\mathrm{c}}$ \\
\hline SimStd & 210 & GMI & $\begin{array}{l}\text { Strahan et al. (2007, 2013), Rotman } \\
\text { et al. (2001), Duncan et al. (2007) }\end{array}$ & $\alpha=0.9946$ \\
\hline SimGC & 384 & GEOS-Chem & Sherwen et al. (2016) & $\alpha=0.9946$ \\
\hline SimTom & 1710 & TOMCAT & Hossaini et al. (2016) & $\begin{array}{l}-2 \%[\mathrm{OH}] \\
\alpha=0.9961\end{array}$ \\
\hline SimTomB & 1710 & TOMCAT & Hossaini et al. (2016) & $\alpha=0.9946$ \\
\hline SimOHp & 210 & GMI & See SimStd & $\begin{array}{l}\text { Not modified for } \\
20 \% \text { higher in } \mathrm{NH}\end{array}$ \\
\hline SimMBL & 2810 & $\begin{array}{l}\text { Tanh function below } \\
900 \mathrm{hPa} \text { over ocean; } \\
\text { GMI elsewhere }\end{array}$ & Allan et al. (2007) & $\begin{array}{l}-4 \%[\mathrm{OH}] \\
\alpha=0.9961\end{array}$ \\
\hline
\end{tabular}

${ }^{a}$ Concentration of $\mathrm{Cl}$ averaged over the troposphere. ${ }^{\mathrm{b}}$ Name of the model that generated the offline $\mathrm{Cl}$ field. ${ }^{\mathrm{c}} \mathrm{Changes}$ to $[\mathrm{OH}]$ or $\alpha_{\mathrm{OH}}$ compared to SimStd.
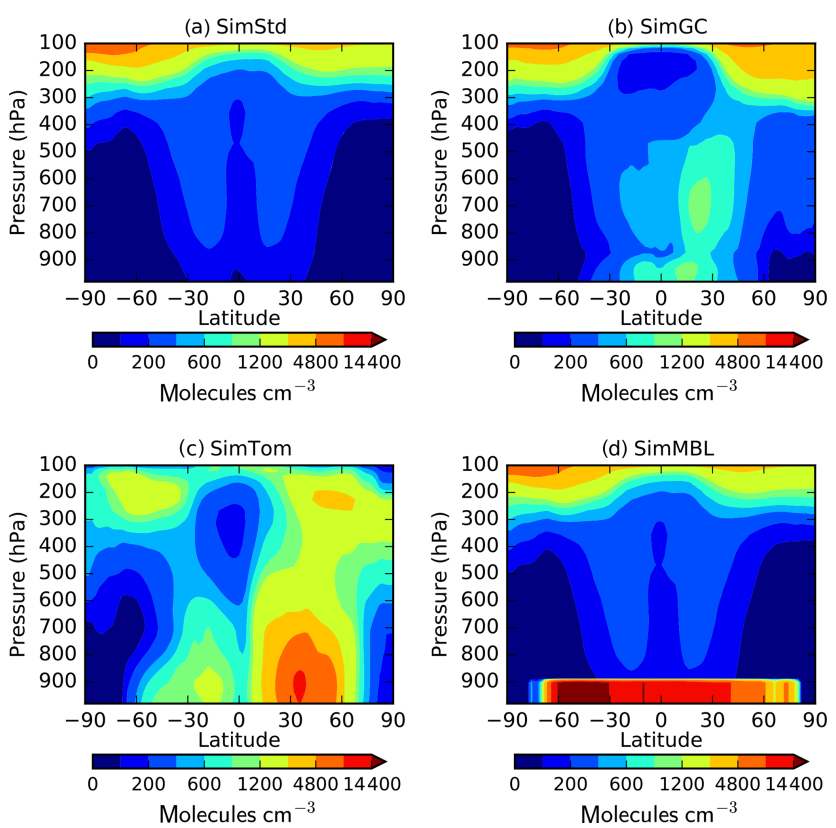

Figure 2. Annual zonal mean $\mathrm{Cl}$ field for (a) SimStd, (b) SimGC, (c) SimTom, and (d) SimMBL.

1990) to avoid too much fractionation from the combined $\mathrm{Cl}$ and $\mathrm{OH}$ sinks. While these changes are necessary to maintain consistent total $\mathrm{CH}_{4}$ and reasonable isotopic ratios, changing multiple factors in addition to $\mathrm{Cl}$ makes it difficult to quantify the impact of $\mathrm{Cl}$ alone. Consequently, we conduct an additional sensitivity study, called SimTomB, which uses the same $\mathrm{Cl}$ field as SimTom but retains the $\mathrm{OH}$ and $\alpha_{\mathrm{OH}}$ values of SimStd. SimTomB is used in Sect. 3.3. This simulation becomes too heavy compared to observations, justifying the need to change $\alpha_{\mathrm{OH}}$ in the main SimTom simulation. We also conduct a sensitivity simulation, $\mathrm{SimOHp}$, that uses the same (a) SimStd

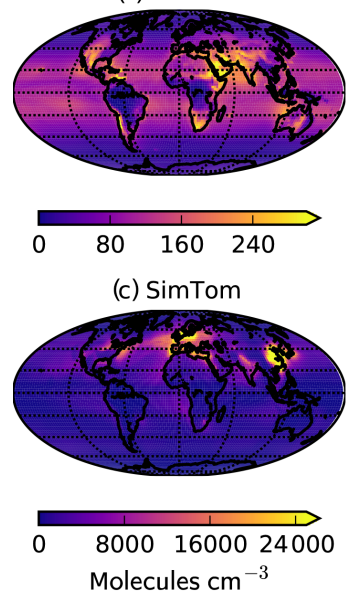

(b) $\operatorname{SimGC}$

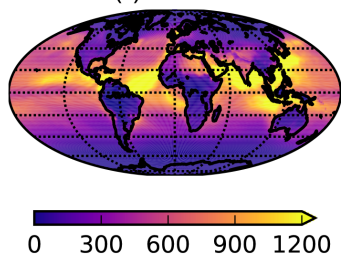

(d) SimMBL

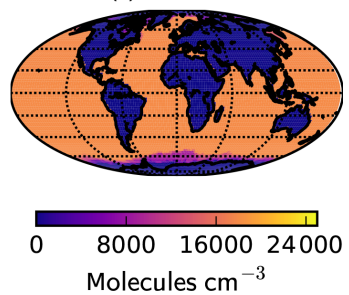

Figure 3. Annual mean surface concentrations of $\mathrm{Cl}$ in (a) SimStd, (b) SimGC, (c) SimTom, and (d) SimMBL. Note the different color scales between panels.

$\mathrm{Cl}$ field as SimStd but does not alter the hemispheric ratio of $\mathrm{OH}$. Table 2 summarizes the standard and sensitivity simulations.

The four $\mathrm{Cl}$ distributions differ in their vertical and horizontal spatial distributions as well as their tropospheric mean (Figs. 2 and 3). The SimStd $\mathrm{Cl}$ is largest in the tropics, is nearly symmetric between hemispheres, and increases with altitude. Both SimGC and SimTom have $\mathrm{Cl}$ that is larger in the Northern Hemisphere than the Southern Hemisphere in the annual mean and reaches a minimum in the midtroposphere. However, the maximum in lower tropospheric $\mathrm{Cl}$ occurs in the tropics in SimGC but in the extratropics in SimTom. This midlatitude $\mathrm{Cl}$ maximum arises because SimTom has high $\mathrm{Cl}$ values over east Asia, whereas $\mathrm{SimGC} \mathrm{Cl}$ is highest over ocean regions (Fig. 3). SimMBL has a strong maxi- 
(a) Jan surface $\mathrm{CH}_{4}$
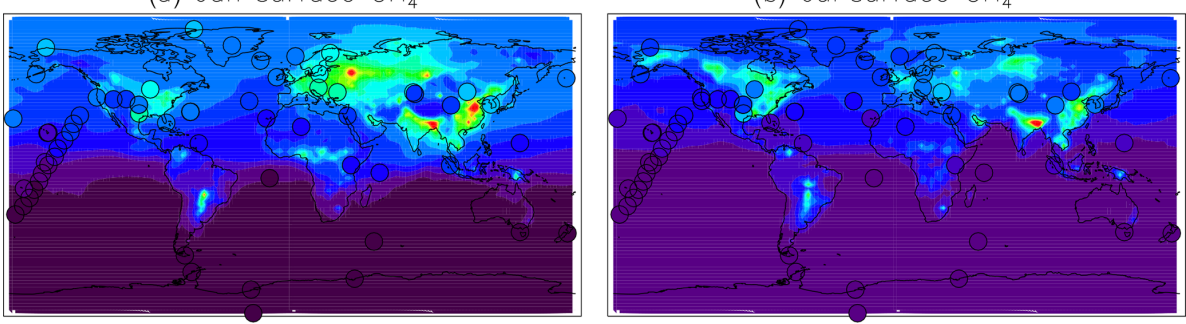

$1700 \quad 1760 \quad 1820 \quad 1880 \quad 1940 \quad 2000$

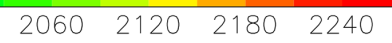

ppb
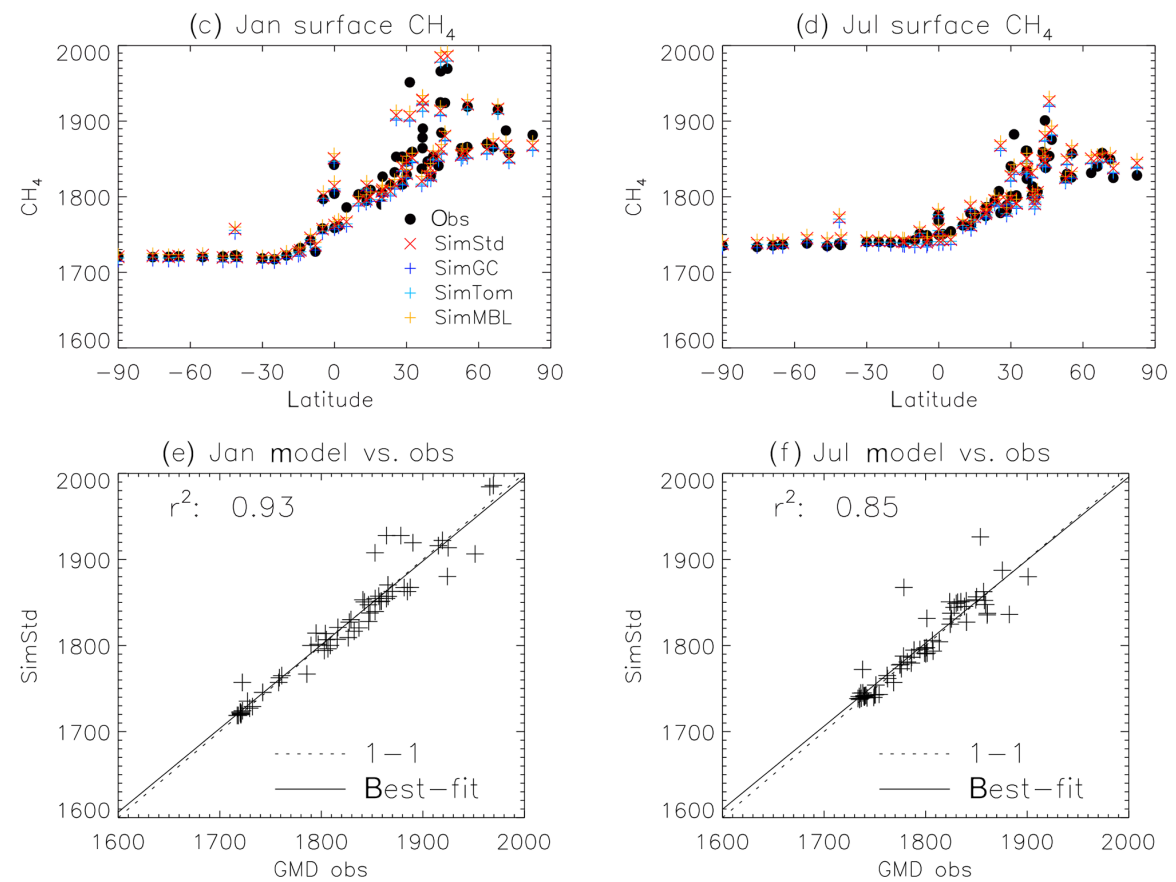

Figure 4. Comparison of 2004 simulated and observed surface $\mathrm{CH}_{4}$ concentrations for January (a, c, e) and July (b, d, f). (a, b) Surface concentrations of $\mathrm{CH}_{4}$ from SimStd are overplotted with the concentrations from the GMD observations in circles. (c, d) GMD observations (black circles), SimStd (red $\times$ ), SimGC (dark blue + ), SimTom (light blue + ), and SimMBL (orange + ) $\mathrm{CH}_{4}$ as a function of latitude. (e, f) SimStd $\mathrm{CH}_{4}(\mathrm{ppb})$ at the observation locations versus the GMD observations (+ signs) as well as the regression line (solid) and one-to-one line (dashed).

mum in the MBL compared to the free troposphere and land regions. Its annual mean $\mathrm{Cl}$ concentrations are higher in the Southern Hemisphere (Fig. 2) due to the larger ocean area in the Southern Hemisphere. However, SimMBL includes a strong seasonal shift in peak $\mathrm{Cl}$ between the hemispheres. SimStd and SimGC have more modest seasonal shifts, while $\mathrm{Cl}$ in SimTom remains concentrated in the Northern Hemisphere throughout the year (Fig. S3). All simulations repeat the same $\mathrm{Cl}$ field from year to year.

The sensitivity simulations listed above are designed to test the role of the $\mathrm{Cl}$ sink. We conduct an additional sensitivity study, SimWet, to illustrate the role of spatial variation in the isotopic source signature. SimWet parallels SimStd, but the isotopic composition of the wetland source uses spa- tial variation from Ganesan et al. (2018). The global mean source signature of the wetland emissions remains $-60 \%$.

\subsection{Observations}

We use surface observations from the NOAA GMD Carbon Cycle Cooperative Global Air Sampling Network to evaluate our simulations. We use the monthly mean observations of total $\mathrm{CH}_{4}$ (Dlugokencky et al., 2018) and $\delta^{13} \mathrm{C}$ of $\mathrm{CH}_{4}$ (White et al., 2018) to compare to the monthly mean simulation results. The isotopic measurements were made at the Institute of Arctic and Alpine Research at the University of Colorado and are referenced to the VPDB scale (Zhang and $\mathrm{Li}, 1990)$. The analytical uncertainty of the isotopic measurements is $0.06 \%$. The variability between measurements 
taken in a given month may, however, be larger, so we use the maximum of analytical uncertainty and the within-month standard deviation as the uncertainty in the monthly mean. When multiple years of observations are averaged together, we use the pooled variance to calculate the standard error, thus reducing the error based on the number of years. The GMD observations are located at remote sites, shown in Fig. 4 for $\mathrm{CH}_{4}$ in 2004. Measurements of $\delta^{13} \mathrm{C}$ of $\mathrm{CH}_{4}$ are available at a subset of the sites, shown in Fig. 5.

\section{Results and discussion}

\subsection{Evaluation of simulated $\mathrm{CH}_{4}$}

We find good agreement between the SimStd simulation and the GMD observations for $\mathrm{CH}_{4}$ (Fig. 4) for 2004. We focus on these 2 months to represent the seasonal differences. The latitudinal distribution is well reproduced, and the simulation captures the elevated concentrations of $\mathrm{CH}_{4}$ observed over Europe in January as well as the January versus July differences in concentration. Overall, the spatial correlation between SimStd and the observations is 0.93 in January and 0.85 in July. The sensitivity simulations described in Table 2 have little effect on the $\mathrm{CH}_{4}$ distribution, as shown by the overlapping symbols in Fig. 4c, d.

\subsection{Impact of $\mathrm{Cl}$ on the $\delta^{13} \mathrm{C}$ distribution}

We next examine the distribution of $\delta^{13} \mathrm{C}$ in SimStd compared to observations. Figure 6 shows the time series of observed and simulated $\delta^{13} \mathrm{C}$ for 1998-2004 at the six GMD sites with $\delta^{13} \mathrm{C}$ records covering this time period. We begin the figure at 1998 rather than 1990 due to the lack of data availability in the earlier years. The standard and sensitivity simulations overestimate $\delta^{13} \mathrm{C}$ at the northernmost station, BRW. The observations at the other stations lie within the range of simulations, with most simulations underestimating the observations at the south pole. The differences between the different sensitivity simulations are large compared to the interannual variability in both observed and simulated $\delta^{13} \mathrm{C}$. We focus our subsequent analysis on a single year, 2004.

Figure $5 \mathrm{a}$ and $\mathrm{b}$ show both meridional and zonal variability in $\delta^{13} \mathrm{C}$. Background values are less negative (heavier) in the Southern versus Northern Hemisphere (NH) (Fig. 7), a feature seen more strongly in the observations, but there is also variability due to the different source signatures. Areas of biomass burning, such as tropical Africa, show up as particularly heavy, while regions with large wetland and rice emissions, such as SE Asia, are particularly light. Another prominent feature is the isotopically heavy region in northern Eurasia (around $60^{\circ} \mathrm{N}$ ) in January, which we attribute to the influence of the geologic (including oil, gas, and coal) source in this region (Fig. S2). This signal is less evident in July, when greater influence from boreal wetlands light- ens the isotopic mix. The spatial correlation $\left(r^{2}\right)$ between the SimStd and observed $\delta^{13} \mathrm{C}$ is 0.61 in January and 0.75 in July.

The sensitivity simulations with altered oxidant concentrations alter the global values of $\delta^{13} \mathrm{C}$, but the geographic patterns remain similar to that of SimStd. The larger $\mathrm{Cl}$ sink in SimGC leads to an overall less negative $\delta^{13} \mathrm{C}$, which agrees better than SimStd with observations at Southern Hemisphere (SH) sites but worse in the NH (Figs. 6c, d and 7). The isotopic effect of the larger $\mathrm{Cl}$ sink in SimTom is compensated for by the lower $\mathrm{OH}$ and $\alpha_{\mathrm{OH}}$ values used in that simulation, flattening the interhemispheric gradient (Figs. 6e, $\mathrm{f}$ and 7). In contrast, the very large $\mathrm{MBL} \mathrm{Cl}$ concentrations in SimMBL lead to an overestimate (insufficiently negative) of the observed $\delta^{13} \mathrm{C}$ (Fig. $5 \mathrm{~g}$, h) but strengthen the interhemispheric gradient. We note that since all simulations began with the same initial conditions but have different sinks, the isotopic composition is not in steady state in 2004 and the results of the sensitivity simulations diverge further with additional years of simulation, with SimMBL becoming clearly inconsistent with observations. We note that while these results highlight the differences in $\delta^{13} \mathrm{C}$ imposed by changing $\mathrm{Cl}$, the absolute values of $\delta^{13} \mathrm{C}$, and hence their agreement with observations, would be different for $\mathrm{CH}_{4}$ source mixtures with a different average $\delta^{13} \mathrm{C}$.

Figure 7 reveals an underestimate in the interhemispheric gradient of $\delta^{13} \mathrm{C}$ in both SimStd and the sensitivity runs compared to the GMD observations. Table 3 presents the observed and simulated $\delta^{13} \mathrm{C}$ interhemispheric gradients calculated as the difference between the $\delta^{13} \mathrm{C}$ values averaged over all sites south of $30^{\circ} \mathrm{S}$ and the average over sites north of $30^{\circ} \mathrm{N}$. SimStd and SimGC show similar underestimates of the observed gradient, and the underestimate is more severe in SimTom. The gradient is improved in SimMBL in January. The differences between simulations reflect differences in the locations where $\mathrm{CH}_{4}$ oxidation occurs and the amount and location of isotopic fractionation due to $\mathrm{Cl}$ versus $\mathrm{OH}$. Figure 8 shows that the higher $\mathrm{Cl}$ values over the NH, particularly China, in SimTom versus SimStd lead to more $\mathrm{CH}_{4}$ loss occurring in the $\mathrm{NH}$ and higher (heavier) $\delta^{13} \mathrm{C}$ in the NH. This effect is particularly pronounced over China and Europe. Less fractionation by the OH sink in SimTom leads to lighter values in the SH. Conversely, SimMBL has more loss occurring over the SH oceans in January, leading to heavier $\delta^{13} \mathrm{C}$ in the SH (Fig. 9). This effect is not present in July, when the SimMBL Cl loss shifts to the NH (Fig. S4). The reduced hemispheric difference in $\mathrm{OH}$ in SimOHp leads to a small improvement in the hemispheric gradient in $\delta^{13} \mathrm{C}$.

We further examine the seasonal cycle of $\delta^{13} \mathrm{C}$ in Fig. 10 . We focus on the seasonal cycle at the South Pole Observatory (SPO) site because it is far from large $\mathrm{CH}_{4}$ sources, and thus the seasonal cycle depends strongly on the seasonality of the $\mathrm{CH}_{4}$ sinks. While all simulations lie mostly within the error bars of the observations, SimMBL has the largest seasonal cycle amplitude, overestimating the seasonal cycle at of the SPO observations with a $\delta^{13} \mathrm{C}$ value that is both too 
(a) SimStd, Jan

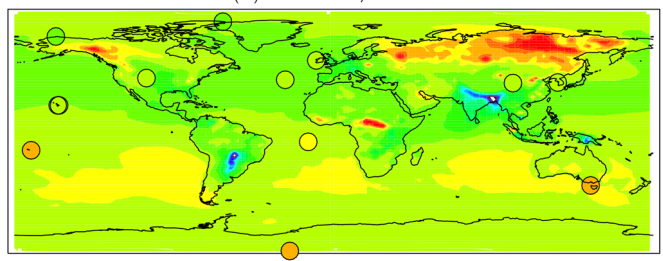

(c) $\operatorname{Sim} G C$, Jan

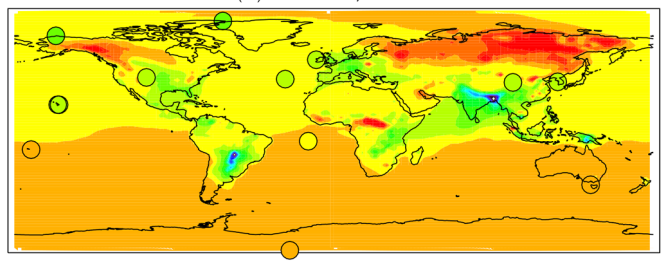

(e) SimTom, Jan

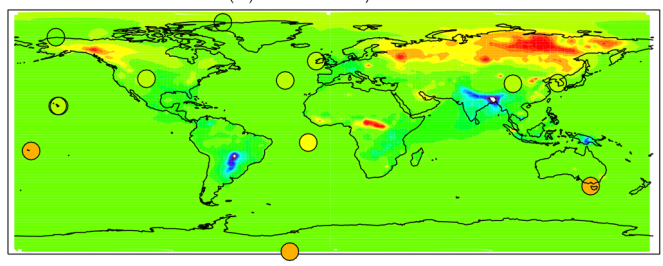

(g) $\operatorname{SimMBL}$, Jan

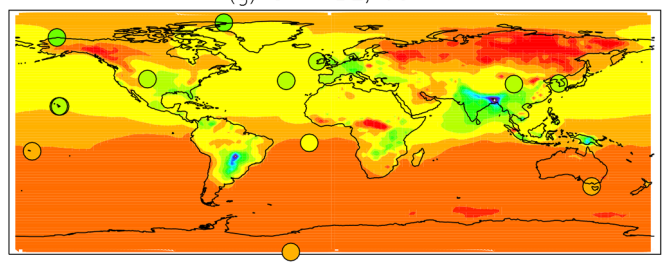

(i) SimWet, Jan

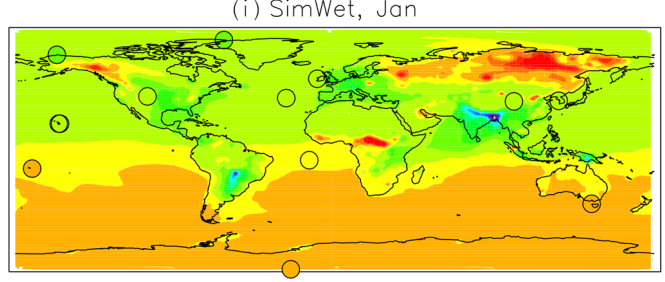

(b) SimStd, Jul

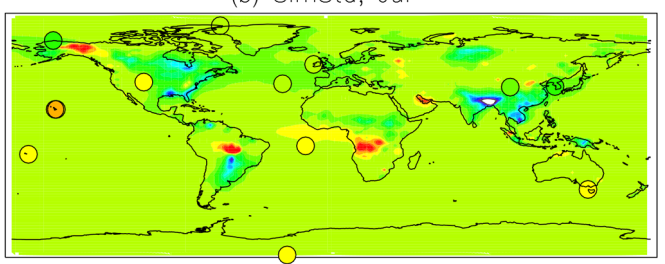

(d) $\operatorname{sim} G C$, Jul

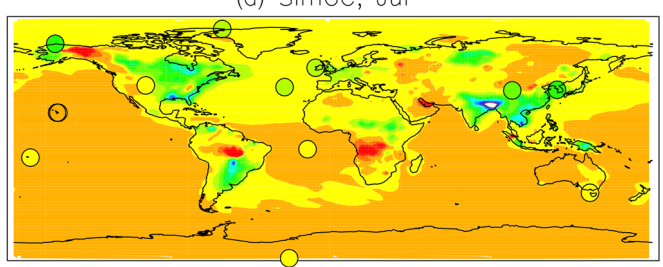

(f) SimTom, Jul

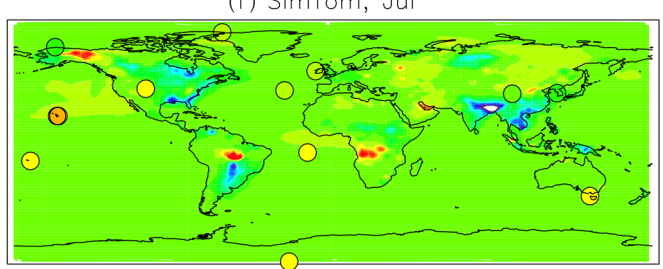

(h) $\operatorname{Sim} M B L$, Jul

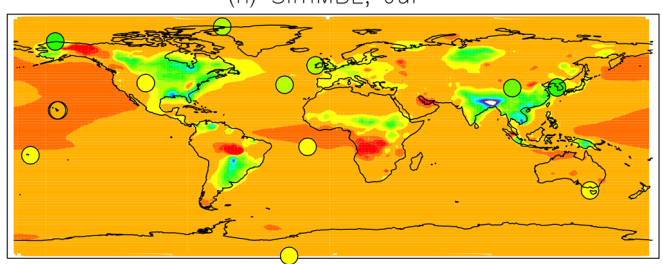

(j) SimWet, Ju

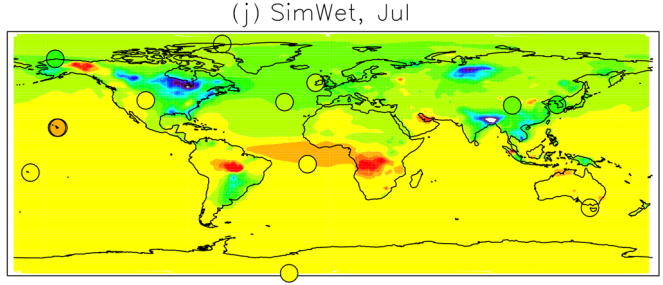

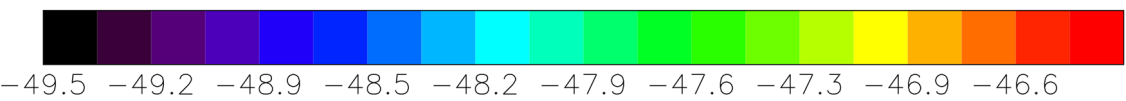

Figure 5. Maps of the simulated surface $\delta^{13} \mathrm{C}$ of $\mathrm{CH}_{4}$ in per mil for January (left) and July (right) overplotted with observations from the GMD sites (circles). The simulations are (a, b) SimStd, (c, d) SimGC, (e, f) SimTom, (g, h) SimMBL, and (i, j) SimWet.

heavy in February-June and too light in August-November. In contrast, SimStd and the other sensitivity simulations underestimate the magnitude of the observed seasonal cycle at SPO. Figure S5 shows a large enhancement in the seasonal cycle amplitude between SimMBL and the other simulations for the Cape Grim site in Tasmania (CGO) but only a small change at other sites. This suggests that while $\mathrm{MBL} \mathrm{Cl}$ is attractive as an explanation for the $\mathrm{SH}$ seasonality of $\delta^{13} \mathrm{C}$, this explanation may be inconsistent with the inclusion of nonmarine $\mathrm{Cl}$ sources. However, since the seasonal cycle amplitude at SPO lies in between SimMBL and the other simula- tions, it is possible that at an $\mathrm{MBL} \mathrm{Cl}$ source similar to that of SimMBL but with a smaller average value could reproduce the amplitude well.

\subsection{Quantifying the sensitivity of $\delta^{13} \mathrm{C}$ to $\mathrm{CH}_{4}$ loss by $\mathbf{C l}$}

Given the substantial range in estimates for how much methane is lost by reaction with tropospheric $\mathrm{Cl}$, it is important to quantify the sensitivity of global mean surface $\delta^{13} \mathrm{C}$ to the $\mathrm{CH}_{4}$ loss by $\mathrm{Cl}$. This analysis summarizes the global im- 

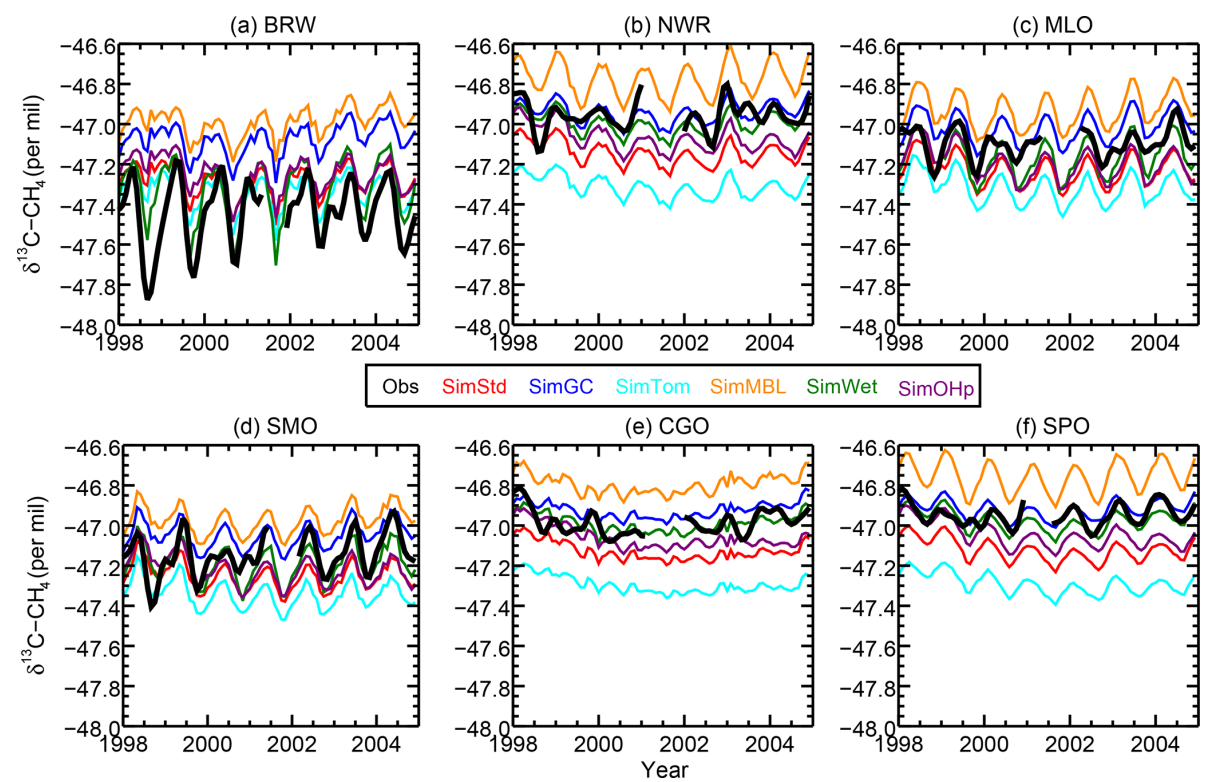

Figure 6. The time series of observed (black) and simulated (colors) $\delta^{13} \mathrm{CH}_{4}$ at the six GMD sites with records extending back to 1998 . BRW: $71.3^{\circ} \mathrm{N}, 156.6^{\circ} \mathrm{W}$; NWR: $40.0^{\circ} \mathrm{N}, 105.6^{\circ} \mathrm{W}$; MLO: $19.5^{\circ} \mathrm{N}, 155.6^{\circ} \mathrm{W}$; CGO: $40.7^{\circ} \mathrm{S}, 144.7^{\circ} \mathrm{E}$; and SPO: $90.0^{\circ} \mathrm{S}, 24.8^{\circ} \mathrm{W}$.
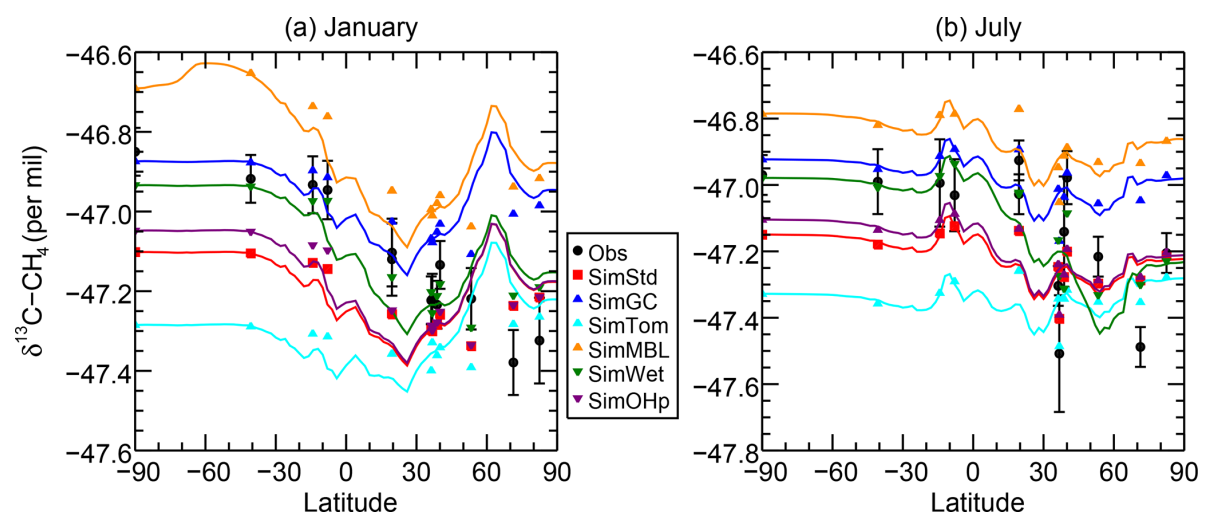

Figure 7. $\delta^{13} \mathrm{C}$ of $\mathrm{CH}_{4}$ as a function of latitude in (a) January and (b) July 2004 for the GMD observations (black circles), SimStd (red), SimGC (dark blue), SimTom (cyan), SimMBL (orange), SimWet (green), and SimOHp (purple). Error bars represent the maximum of the analytical uncertainty $(0.06 \%$ ) and the standard deviation of individual measurements in the month for each site. The colored lines represent the simulated zonal mean, while the colored symbols represent the simulation sampled at the location of the GMD observations.

pact of the isotopic effect of the $\mathrm{Cl}$ differences between simulations discussed above. Figure 11 shows the global mean, area-weighted surface $\delta^{13} \mathrm{C}$ in 2004 as a function of the percent of $\mathrm{CH}_{4}$ oxidized by $\mathrm{Cl}$ for SimStd, SimGC, and SimTomB, the three simulations with the same $\mathrm{OH}$ and emissions but different $\mathrm{Cl}$. A strong linear relationship is evident between the oxidation by $\mathrm{Cl}$ and the surface $\delta^{13} \mathrm{C}$. The slope of the linear regression line indicates the expected increase in surface $\delta^{13} \mathrm{C}$ for a change in the percent of $\mathrm{CH}_{4}$ oxidized by $\mathrm{Cl}$. Based on this analysis we expect that surface $\delta^{13} \mathrm{C}$ will increase by approximately $0.5 \%$ for each percent increase in $\mathrm{CH}_{4}$ loss by $\mathrm{Cl}$.

\subsection{Sensitivity of $\delta^{13} \mathrm{C}$ to the isotopic distribution of sources}

Other factors in addition to the $\mathrm{Cl}$ distribution likely contribute to the mismatch between the observed and simulated interhemispheric gradients. Figure 5 shows the impact of the geologic source on the $\delta^{13} \mathrm{C}$ values over northern Asia. A bias in either the strength or the isotopic composition of this source will impact the interhemispheric gradient. Another likely contributing factor is our use of a globally uniform isotopic ratio for each source type. Ganesan et al. (2018) developed a global map of the isotopic signatures of wetland emissions. We use this map to impose spatially varying isotopic ratios on our SimWet simulation. SimWet increases 
Table 3. Observed and simulated interhemispheric gradient in $\delta^{13} \mathrm{C}-\mathrm{CH}_{4}$.

\begin{tabular}{lrr}
\hline & $\begin{array}{r}\text { January gradient } \\
(\% \circ)^{*}\end{array}$ & $\begin{array}{r}\text { July gradient } \\
(\% \circ)^{*}\end{array}$ \\
\hline GMD observations & 0.36 & 0.28 \\
SimStd & 0.17 & 0.11 \\
SimGC & 0.17 & 0.098 \\
SimTom & 0.051 & 0.010 \\
SimMBL & 0.30 & 0.13 \\
SimOHp & 0.22 & 0.15 \\
SimWet & 0.28 & 0.25 \\
\hline
\end{tabular}

* Average $\delta^{13} \mathrm{C}_{-} \mathrm{CH}_{4}$ at GMD site locations south of $30^{\circ} \mathrm{S}$ minus average ${ }^{13} \mathrm{C}^{1} \mathrm{CH}_{4}$ at locations north of $30^{\circ} \mathrm{N}$. (a) $\mathrm{CH}_{4}$ loss
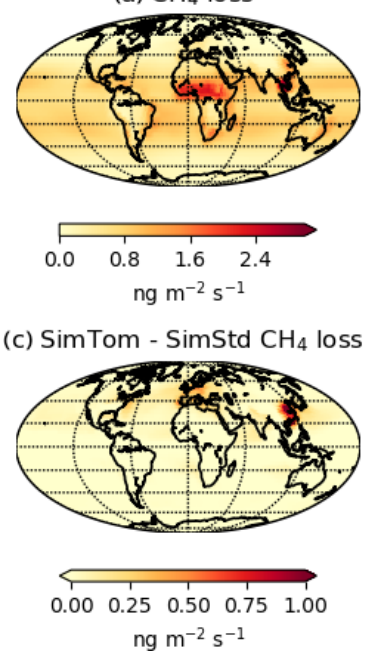

(c) SimTom - SimStd $\mathrm{CH}_{4}$ loss (b) $\mathrm{CH}_{4}$ loss by $\mathrm{Cl}$
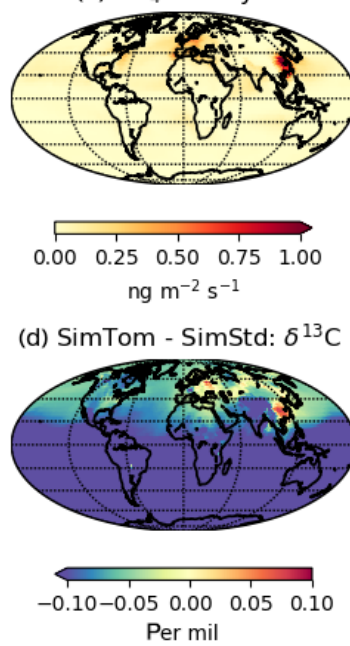

(d) SimTom - SimStd: $\delta^{13} \mathrm{C}$

Figure 8. January (a) $\mathrm{CH}_{4}$ loss and (b) $\mathrm{CH}_{4}$ loss by $\mathrm{Cl}$ only in the SimTom simulation, as well as the difference in (c) $\mathrm{CH}_{4}$ loss and (d) $\delta^{13} \mathrm{C}-\mathrm{CH}_{4}$ between the SimTom and SimStd simulations.

the amplitude of the seasonal cycle in $\delta^{13} \mathrm{C}-\mathrm{CH}_{4}$ particularly for northern latitudes sites such as ALT, BRW, and MHD (Fig. S5). It has little effect on the seasonal cycle at the SH CGO and SPO sites, where SimMBL shows a large effect on the cycle. SimWet results in improved agreement with the observed interhemispheric gradient (Figs. 5, 7; Table 3). SimWet is better able to simultaneously match the $\delta^{13} \mathrm{C}-\mathrm{CH}_{4}$ observations at both the northernmost (BRW) and southernmost (SPO) sites shown in Fig. 6 than the other simulations, even though all simulations reproduce the latitudinal distribution of $\mathrm{CH}_{4}$ well (Fig. 4). This highlights the importance of spatially varying isotopic ratios for the $\delta^{13} \mathrm{C}-\mathrm{CH}_{4}$ distribution. The size of the effect of including spatially varying ratios in wetland emissions depends on the strength of the wetland emissions as well as the other sources. Including spatially varying isotopic signature for other sources as well could further modify the simulated interhemispheric gradi-
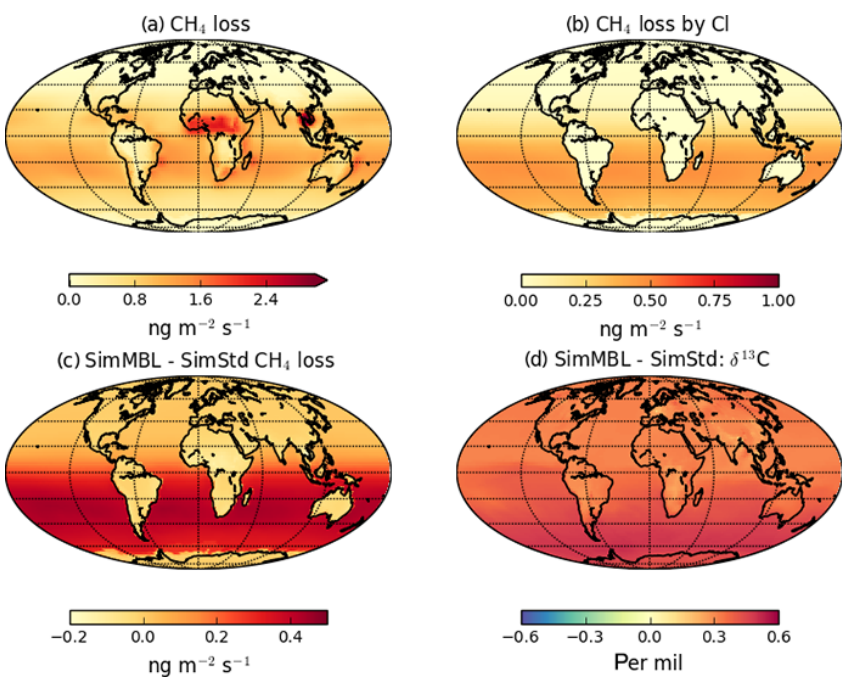

Figure 9. January (a) $\mathrm{CH}_{4}$ loss and (b) $\mathrm{CH}_{4}$ loss by $\mathrm{Cl}$ only in the SimMBL simulation, as well as the difference in (c) $\mathrm{CH}_{4}$ loss and (d) ${ }^{13} \mathrm{C}-\mathrm{CH}_{4}$ between the SimMBL and SimStd simulations.

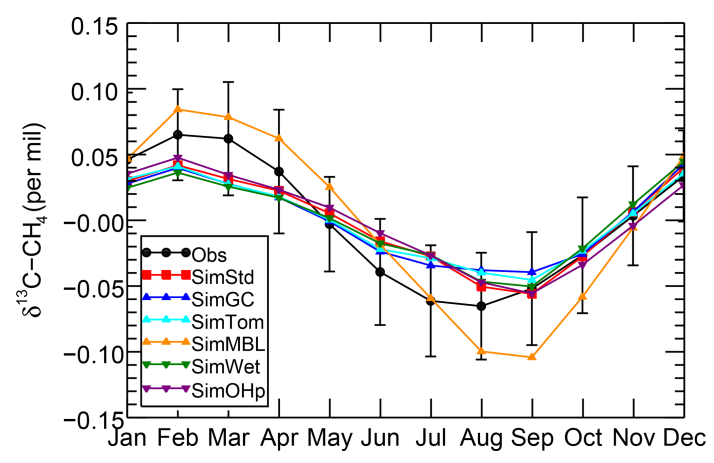

Figure 10. The seasonal cycle of $\delta^{13} \mathrm{C}$ of $\mathrm{CH}_{4}$ at the SPO site with the annual mean removed averaged over 2002-2004 for the GMD observations (black), SimStd (red), SimGC (blue), SimTom (cyan), SimMBL (orange), SimWet (green), and SimOHp (purple). Error bars represent the standard error, calculated as the maximum of the pooled standard deviation or the analytical uncertainty $(0.06 \%$ ), divided by the square root of the number of years of observations.

ent, potentially correcting some of the flat gradient of, e.g., the SimTom simulation.

\section{Conclusions}

The role of $\mathrm{Cl}$ as a methane sink is a significant uncertainty in the global $\mathrm{CH}_{4}$ budget, particularly with respect to isotopes. The global distribution of $\mathrm{Cl}$ is not well known from observations, and the $\mathrm{Cl}$ distributions simulated by global models vary widely from model to model. We investigated the sensitivity of the surface $\delta^{13} \mathrm{C}$ distribution of $\mathrm{CH}_{4}$ to the intermodel diversity in tropospheric $\mathrm{Cl}$ using a series of sensitivity studies with a global 3D model. Given the uncertainties 


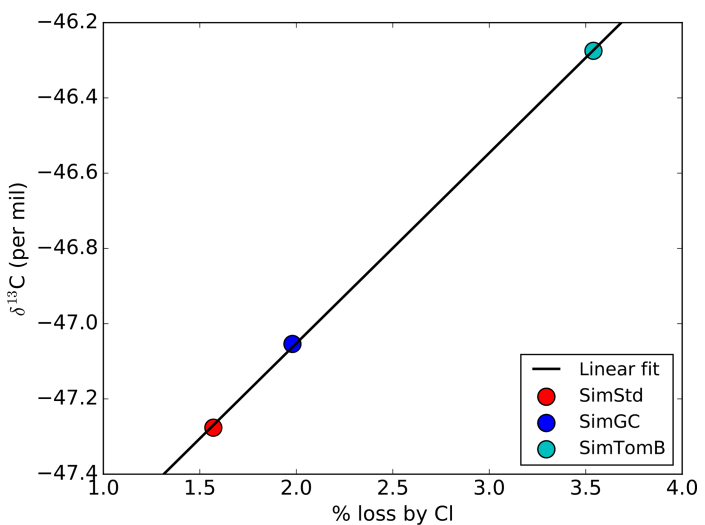

Figure 11. Area-weighted global mean surface $\delta^{13} \mathrm{C}$ for the SimStd (red), SimGC (blue), and SimTomB (cyan) simulations in 2004 as a function of the percent of $\mathrm{CH}_{4}$ loss occurring by reaction with $\mathrm{Cl}$. The linear best-fit line is shown in black.

in $\mathrm{CH}_{4}$ sources and their isotopic ratios, it is not possible to conclude from this study which $\mathrm{Cl}$ field is best. However, the differences between the simulations provide insight on the strong lever that tropospheric $\mathrm{Cl}$ exerts on the $\delta^{13} \mathrm{C}$ distribution.

Our standard and sensitivity simulations all reproduce well the geographic distribution of and temporal evolution of $\mathrm{CH}_{4}$ observed at the GMD surface sites. However, imposing $\mathrm{Cl}$ distributions from a range of chemical transport models used in the scientific community leads to large differences in the simulated distribution of the $\delta^{13} \mathrm{C}$ of $\mathrm{CH}_{4}$. The $\mathrm{CH}_{4}$ sinks from $\mathrm{Cl}$ in our SimStd and SimGC simulations are both below $1 \%$ of the total $\mathrm{CH}_{4}$ sink, as suggested by Gromov et al. (2018). Yet the SimStd and SimGC simulations underestimate and overestimate, respectively, the observed $\delta^{13} \mathrm{C}$ in 2004, despite the fact that both include only a relatively small $\mathrm{CH}_{4}$ sink from $\mathrm{Cl}$.

Our ability to reproduce the observed latitudinal distribution of $\delta^{13} \mathrm{C}$ depends not only on the assumed value of global mean $\mathrm{Cl}$, but also its geographic distribution. The detailed halogen chemistry model (TOMCAT) of Hossaini et al. (2016) places the maximum $\mathrm{Cl}$ values in the continental $\mathrm{NH}$, in contrast to the large MBL Cl sink used in Allan et al. (2007) to explain SH observations. We find that the strong $\mathrm{NH} \mathrm{Cl}$ maximum, along with the resulting reduction in $\mathrm{OH}$ fractionation required to maintain consistency with observations, acts to flatten the interhemispheric gradient of $\delta^{13} \mathrm{C}$, while the MBL Cl sink increases the hemispheric differences in $\mathrm{NH}$ winter and also strengthens the seasonal cycle. However, the interhemispheric gradient is also influenced by spatial variation in the isotopic signatures of the sources and uncertainties in the soil sink, complicating this issue.

Two values for the fractionating effect of $\mathrm{OH}\left(\alpha_{\mathrm{OH}}\right)$ on $\delta^{13} \mathrm{C}$ (Cantrell et al., 1990; Saueressig et al., 2001) are widely cited in the literature. Combining the TOMCAT $\mathrm{Cl}$ fields with the $\alpha_{\mathrm{OH}}$ of Saueressig et al. (2001) leads to an underes- timate of observed $\delta^{13} \mathrm{C}$, but combining it with the Cantrell et al. (1990) $\alpha_{\mathrm{OH}}$ would lead to an overestimate. Reducing uncertainty in the fractionating effect of $\mathrm{OH}$ would thus improve our ability to constrain the role of $\mathrm{Cl}$.

Observations of the $\delta^{13} \mathrm{C}$ of $\mathrm{CH}_{4}$ provide an important tool for constraining the $\mathrm{CH}_{4}$ budget. We find that the range of $\mathrm{Cl}$ fields available from current global models leads to a wide range of simulated $\delta^{13} \mathrm{C}$ values. Each percent increase in the amount of $\mathrm{CH}_{4}$ loss occurring by reaction with $\mathrm{Cl}$ increases global mean surface $\delta^{13} \mathrm{C}$ of $\mathrm{CH}_{4}$ by approximately $0.5 \%$. This relationship can be used to estimate the impact on methane's isotopic values from future model simulations of $\mathrm{Cl}$. The choice of $\mathrm{Cl}$ field thus strongly impacts what $\mathrm{CH}_{4}$ source mixture best fits $\delta^{13} \mathrm{C}$ observations. Better quantification of the role of $\mathrm{Cl}$ in the methane budget and further developing models of tropospheric halogens are therefore critical for interpreting the $\delta^{13} \mathrm{C}$ observations to their fullest potential.

Data availability. The methane (Dlugokencky et al., 2018) and $\delta^{13} \mathrm{CH}_{4}$ (White et al., 2018) observations are available from the NOAA GMD website: https://www.esrl.noaa.gov/gmd/dv/data/ (Global Monitoring Laboratory, 2020). Output from the GEOS model is on the NASA Center for Climate Simulation (NCCS) system.

Supplement. The supplement related to this article is available online at: https://doi.org/10.5194/acp-20-8405-2020-supplement.

Author contributions. SAS designed and conducted the simulations, performed the analysis, and prepared the manuscript. JSW contributed to model development and experiment design. MM contributed to model development. BD contributed to model development and conceptualization. RH and CAK contributed inputs to the simulations. SEM and JWCW contributed data and aided in their interpretation. All authors contributed to the editing and revising of the manuscript.

Competing interests. The authors declare that they have no conflict of interest.

Acknowledgements. Computational resources were provided by the NASA Center for Climate Simulation (NCCS). The authors thank Prabir Patra for useful discussions. Ryan Hossaini is supported by a NERC Independent Research Fellowship (NE/N014375/1).

Review statement. This paper was edited by Patrick Jöckel and reviewed by two anonymous referees. 


\section{References}

Allan, W., Manning, M. R., Lassey, K. R., Lowe, D. C., and Gomez, A. J.: Modeling the variation of $\delta^{13} \mathrm{C}$ in atmospheric methane: Phase ellipses and the kinetic isotope effect, Global Biogeochem. Cy., 15, 467-481, https://doi.org/10.1029/2000GB001282, 2001.

Allan, W., Struthers, H., and Lowe, D.: Methane carbon isotope effects caused by atomic chlorine in the marine boundary layer: Global model results compared with Southern Hemisphere measurements, J. Geophys. Res.-Atmos., 112, D04306, https://doi.org/10.1029/2006JD007369, 2007.

Bock, M., Schmitt, J., Beck, J., Seth, B., Chappellaz, J., and Fischer, H.: Glacial/interglacial wetland, biomass burning, and geologic methane emissions constrained by dual stable isotopic $\mathrm{CH}_{4}$ ice core records, P. Natl. Acad. Sci. USA, 114, E5778-E5786, https://doi.org/10.1073/pnas.1613883114, 2017.

Brownlow, R., Lowry, D., Fisher, R., France, J., Lanoisellé, M., White, B., Wooster, M., Zhang, T., and Nisbet, E.: Isotopic ratios of tropical methane emissions by atmospheric measurement, Global Biogeochem. Cy., 31, 1408-1419, 2017.

Cantrell, C. A., Shetter, R. E., McDaniel, A. H., Calvert, J. G., Davidson, J. A., Lowe, D. C., Tyler, S. C., Cicerone, R. J., and Greenberg, J. P.: Carbon kinetic isotope effect in the oxidation of methane by the hydroxyl radical, J. Geophys. Res.-Atmos., 95, 22455-22462, 1990.

Craig, H.: Isotopic Standards for Carbon and Oxygen and Correction Factors for Mass-Spectrometric Analysis OF Carbon Dioxide, Geochim. Cosmochim. Ac., 12, 133-149, https://doi.org/10.1016/0016-7037(57)90024-8, 1957.

Dlugokencky, E., Bruhwiler, L., White, J., Emmons, L., Novelli, P., Montzka, S., Masarie, K., Lang, P., Crotwell, A., Miller, J., and Gatti, L.: Observational constraints on recent increases in the atmospheric $\mathrm{CH}_{4}$ burden, Geophys. Res. Lett., 36, L18803, https://doi.org/10.1029/2009GL039780, 2009.

Dlugokencky, E., Nisbet, E., Fisher, R., and Lowry, D.: Global atmospheric methane: budget, changes and dangers, Philos. T. R. Soc. A, 369, 2058-2072, https://doi.org/10.1098/rsta.2010.0341, 2011.

Dlugokencky, E. J., Lang, P. M., Crotwell, A. M., Mund, J. W., Crotwell, M. J., and Thoning, K. W.: Atmospheric Methane Dry Air Mole Fractions from the NOAA ESRL Carbon Cycle Cooperative Global Air Sampling Network, 1983-2017, Version: 2018-08-01, available at: ftp://aftp.cmdl.noaa.gov/data/ trace_gases/ch4/flask/surface/ (last access: 30 January 2019), 2018.

Duncan, B. N., Strahan, S. E., Yoshida, Y., Steenrod, S. D., and Livesey, N.: Model study of the cross-tropopause transport of biomass burning pollution, Atmos. Chem. Phys., 7, 3713-3736, https://doi.org/10.5194/acp-7-3713-2007, 2007.

Elshorbany, Y. F., Duncan, B. N., Strode, S. A., Wang, J. S., and Kouatchou, J.: The description and validation of the computationally Efficient $\mathrm{CH}_{4}-\mathrm{CO}-\mathrm{OH}$ (ECCOHv1.01) chemistry module for 3-D model applications, Geosci. Model Dev., 9, 799-822, https://doi.org/10.5194/gmd-9-799-2016, 2016.

Etiope, G. and Milkov, A.: A new estimate of global methane flux from onshore and shallow submarine mud volcanoes to the atmosphere, Environ. Geol., 46, 997-1002, https://doi.org/10.1007/s00254-004-1085-1, 2004.

European Commission: Joint Research Center (JRC)/Netherlands Environmental Assessment Agency (PBL), Emission Database for Global Atmospheric Research (EDGAR), available at: http: //edgar.jrc.ec.europe.eu (last access: 6 July 2016), 2011.

Ferretti, D. F., Miller, J. B., White, J. W. C., Etheridge, D. M., Lassey, K. R., Lowe, D. C., Meure, C. M. M., Dreier, M. F., Trudinger, C. M., van Ommen, T. D., and Langenfelds, R. L.: Unexpected Changes to the Global Methane Budget over the Past 2000 Years, Science, 309, 1714-1717, https://doi.org/10.1126/science.1115193, 2005.

Fischer, H., Behrens, M., Bock, M., Richter, U., Schmitt, J., Loulergue, L., Chappellaz, J., Spahni, R., Blunier, T., Leuenberger, M., and Stocker, T. F.: Changing boreal methane sources and constant biomass burning during the last termination, Nature, 452, 864, https://doi.org/10.1038/nature06825, 2008.

Fung, I., John, J., Lerner, J., Matthews, E., Prather, M., Steele, L., and Fraser, P.: 3-Dimensional Model Synthesis of the Global Methane Cycle, J. Geophys. Res.-Atmos., 96, 13033-13065, https://doi.org/10.1029/91JD01247, 1991.

Ganesan, A., Stell, A., Gedney, N., Comyn-Platt, E., Hayman, G., Rigby, M., Poulter, B., and Hornibrook, E.: Spatially Resolved Isotopic Source Signatures of Wetland Methane Emissions, Geophys. Res. Lett., 45, 3737-3745, 2018.

Gelaro, R., McCarty, W., Suarez, M., Todling, R., Molod, A., Takacs, L., Randles, C., Darmenov, A., Bosilovich, M., Reichle, R., Wargan, K., Coy, L., Cullather, R., Draper, C., Akella, S., Buchard, V., Conaty, A., da Silva, A., Gu, W., Kim, G., Koster, R., Lucchesi, R., Merkova, D., Nielsen, J., Partyka, G., Pawson, S., Putman, W., Rienecker, M., Schubert, S., Sienkiewicz, M., and Zhao, B.: The Modern-Era Retrospective Analysis for Research and Applications, Version 2 (MERRA-2), J. Climate, 30, 5419-5454, https://doi.org/10.1175/JCLI-D-16-0758.1, 2017.

Ghosh, A., Patra, P. K., Ishijima, K., Umezawa, T., Ito, A., Etheridge, D. M., Sugawara, S., Kawamura, K., Miller, J. B., Dlugokencky, E. J., Krummel, P. B., Fraser, P. J., Steele, L. P., Langenfelds, R. L., Trudinger, C. M., White, J. W. C., Vaughn, B., Saeki, T., Aoki, S., and Nakazawa, T.: Variations in global methane sources and sinks during 1910-2010, Atmos. Chem. Phys., 15, 2595-2612, https://doi.org/10.5194/acp15-2595-2015, 2015.

Global Monitoring Laboratory: GML Data Finder, available at: https://www.esrl.noaa.gov/gmd/dv/data/, last access: 13 July 2020.

Granier, C., Bessagnet, B., Bond, T., D’Angiola, A., van der Gon, H. D., Frost, G. J., Heil, A., Kaiser, J. W., Kinne, S., Klimont, Z., Kloster, S., Lamarque, J. F., Liousse, C., Masui, T., Meleux, F., Mieville, A., Ohara, T., Raut, J. C., Riahi, K., Schultz, M. G., Smith, S. J., Thompson, A., van Aardenne, J., van der Werf, G. R., and van Vuuren, D. P.: Evolution of anthropogenic and biomass burning emissions of air pollutants at global and regional scales during the $1980-2010$ period, Climatic Change, 109, 163-190, https://doi.org/10.1007/s10584011-0154-1, 2011.

Gromov, S., Brenninkmeijer, C. A. M., and Jöckel, P.: A very limited role of tropospheric chlorine as a sink of the greenhouse gas methane, Atmos. Chem. Phys., 18, 9831-9843, https://doi.org/10.5194/acp-18-9831-2018, 2018.

Hausmann, P., Sussmann, R., and Smale, D.: Contribution of oil and natural gas production to renewed increase in atmospheric methane (2007-2014): top-down estimate from ethane 
and methane column observations, Atmos. Chem. Phys., 16, 3227-3244, https://doi.org/10.5194/acp-16-3227-2016, 2016.

Hopcroft, P. O., Valdes, P. J., and Kaplan, J. O.: Bayesian Analysis of the Glacial-Interglacial Methane Increase Constrained by Stable Isotopes and Earth System Modeling, Geophys. Res. Lett., 45, 3653-3663, https://doi.org/10.1002/2018GL077382, 2018.

Hossaini, R., Chipperfield, M. P., Saiz-Lopez, A., Fernandez, R., Monks, S., Feng, W., Brauer, P., and von Glasow, R.: A global model of tropospheric chlorine chemistry: Organic versus inorganic sources and impact on methane oxidation, J. Geophys. Res.-Atmos., 121, 14271-14297, https://doi.org/10.1002/2016JD025756, 2016.

Houweling, S., Kaminski, T., Dentener, F., Lelieveld, J., and Heimann, M.: Inverse modeling of methane sources and sinks using the adjoint of a global transport model, J. Geophys. Res.-Atmos., 104, 26137-26160, https://doi.org/10.1029/1999JD900428, 1999.

Houweling, S., Dentener, F., and Lelieveld, J.: Simulation of preindustrial atmospheric methane to constrain the global source strength of natural wetlands, J. Geophys. Res.-Atmos., 105, 17243-17255, https://doi.org/10.1029/2000JD900193, 2000.

Houweling, S., Van der Werf, G., Goldewijk, K. K., Röckmann, T., and Aben, I.: Early anthropogenic $\mathrm{CH}_{4}$ emissions and the variation of $\mathrm{CH}_{4}$ and ${ }^{13} \mathrm{CH}_{4}$ over the last millennium, Global Biogeochem. Cy., 22, GB1002, https://doi.org/10.1029/2007GB002961, 2008.

Hu, L., Keller, C. A., Long, M. S., Sherwen, T., Auer, B., Da Silva, A., Nielsen, J. E., Pawson, S., Thompson, M. A., Trayanov, A. L., Travis, K. R., Grange, S. K., Evans, M. J., and Jacob, D. J.: Global simulation of tropospheric chemistry at $12.5 \mathrm{~km}$ resolution: performance and evaluation of the GEOS-Chem chemical module (v10-1) within the NASA GEOS Earth system model (GEOS-5 ESM), Geosci. Model Dev., 11, 4603-4620, https://doi.org/10.5194/gmd-11-4603-2018, 2018.

Ito, A. and Inatomi, M.: Use of a process-based model for assessing the methane budgets of global terrestrial ecosystems and evaluation of uncertainty, Biogeosciences, 9, 759-773, https://doi.org/10.5194/bg-9-759-2012, 2012.

Kai, F., Tyler, S., Randerson, J., and Blake, D.: Reduced methane growth rate explained by decreased Northern Hemisphere microbial sources, Nature, 476, 194-197, https://doi.org/10.1038/nature10259, 2011.

Kirschke, S., Bousquet, P., Ciais, P., Saunois, M., Canadell, J. G., Dlugokencky, E. J., Bergamaschi, P., Bergmann, D., Blake, D. R., Bruhwiler, L., Cameron-Smith, P., Castaldi, S., Chevallier, F., Feng, L., Fraser, A., Heimann, M., Hodson, E. L., Houweling, S., Josse, B., Fraser, P. J., Krummel, P. B., Lamarque, J.F., Langenfelds, R. L., Le Quere, C., Naik, V., O’Doherty, S., Palmer, P. I., Pison, I., Plummer, D., Poulter, B., Prinn, R. G., Rigby, M., Ringeval, B., Santini, M., Schmidt, M., Shindell, D. T., Simpson, I. J., Spahni, R., Steele, L. P., Strode, S. A., Sudo, K., Szopa, S., van der Werf, G. R., Voulgarakis, A., van Weele, M., Weiss, R. F., Williams, J. E., and Zeng, G.: Three decades of global methane sources and sinks, Nat. Geosci., 6, 813-823, https://doi.org/10.1038/NGEO1955, 2013.

Lassey, K. R., Etheridge, D. M., Lowe, D. C., Smith, A. M., and Ferretti, D. F.: Centennial evolution of the atmospheric methane budget: what do the carbon isotopes tell us?, Atmos. Chem. Phys., 7, 2119-2139, https://doi.org/10.5194/acp-7-2119-2007, 2007.
Long, M. S., Yantosca, R., Nielsen, J. E., Keller, C. A., da Silva, A., Sulprizio, M. P., Pawson, S., and Jacob, D. J.: Development of a grid-independent GEOS-Chem chemical transport model (v9-02) as an atmospheric chemistry module for Earth system models, Geosci. Model Dev., 8, 595-602, https://doi.org/10.5194/gmd-8-595-2015, 2015.

McNorton, J., Chipperfield, M. P., Gloor, M., Wilson, C., Feng, W., Hayman, G. D., Rigby, M., Krummel, P. B., O’Doherty, S., Prinn, R. G., Weiss, R. F., Young, D., Dlugokencky, E., and Montzka, S. A.: Role of $\mathrm{OH}$ variability in the stalling of the global atmospheric $\mathrm{CH}_{4}$ growth rate from 1999 to 2006, Atmos. Chem. Phys., 16, 7943-7956, https://doi.org/10.5194/acp16-7943-2016, 2016.

Mikaloff Fletcher, S. E., Tans, P. P., Bruhwiler, L. M., Miller, J. B., and Heimann, M.: $\mathrm{CH}_{4}$ sources estimated from atmospheric observations of $\mathrm{CH}_{4}$ and its ${ }^{13} \mathrm{C} /{ }^{12} \mathrm{C}$ isotopic ratios: 2. Inverse modeling of $\mathrm{CH}_{4}$ fluxes from geographical regions, Global Biogeochem. Cy., 18, GB4005, https://doi.org/10.1029/2004GB002224, 2004a.

Mikaloff Fletcher, S. E., Tans, P. P., Bruhwiler, L. M., Miller, J. B., and Heimann, M.: $\mathrm{CH}_{4}$ sources estimated from atmospheric observations of $\mathrm{CH}_{4}$ and its ${ }^{13} \mathrm{C} /{ }^{12} \mathrm{C}$ isotopic ratios: 1. Inverse modeling of source processes, Global Biogeochem. Сy., 18, GB4004, https://doi.org/10.1029/2004GB002223, 2004 b.

Molod, A., Takacs, L., Suarez, M., and Bacmeister, J.: Development of the GEOS-5 atmospheric general circulation model: evolution from MERRA to MERRA2, Geosci. Model Dev., 8, 1339-1356, https://doi.org/10.5194/gmd-8-1339-2015, 2015.

Monteil, G., Houweling, S., Dlugockenky, E. J., Maenhout, G., Vaughn, B. H., White, J. W. C., and Rockmann, T.: Interpreting methane variations in the past two decades using measurements of $\mathrm{CH}_{4}$ mixing ratio and isotopic composition, Atmos. Chem. Phys., 11, 9141-9153, https://doi.org/10.5194/acp11-9141-2011, 2011.

Naik, V., Voulgarakis, A., Fiore, A. M., Horowitz, L. W., Lamarque, J.-F., Lin, M., Prather, M. J., Young, P. J., Bergmann, D., Cameron-Smith, P. J., Cionni, I., Collins, W. J., Dalsøren, S. B., Doherty, R., Eyring, V., Faluvegi, G., Folberth, G. A., Josse, B., Lee, Y. H., MacKenzie, I. A., Nagashima, T., van Noije, T. P. C., Plummer, D. A., Righi, M., Rumbold, S. T., Skeie, R., Shindell, D. T., Stevenson, D. S., Strode, S., Sudo, K., Szopa, S., and Zeng, G.: Preindustrial to present-day changes in tropospheric hydroxyl radical and methane lifetime from the Atmospheric Chemistry and Climate Model Intercomparison Project (ACCMIP), Atmos. Chem. Phys., 13, 5277-5298, https://doi.org/10.5194/acp13-5277-2013, 2013.

Nielsen, J., Pawson, S., Molod, A., Auer, B., da Silva, A., Douglass, A., Duncan, B., Liang, Q., Manyin, M., Oman, L., Putman, W., Strahan, S., and Wargan, K.: Chemical Mechanisms and Their Applications in the Goddard Earth Observing System (GEOS) Earth System Model, J. Adv. Model. Earth Sy., 9, 3019-3044, https://doi.org/10.1002/2017MS001011, 2017.

Nisbet, E., Dlugokencky, E., Manning, M., Lowry, D., Fisher, R., France, J., Michel, S., Miller, J., White, J., and Vaughn, B.: Rising atmospheric methane: 2007-2014 growth and isotopic shift, Global Biogeochem. Cy., 30, 1356-1370, 2016.

Nisbet, E., Manning, M., Dlugokencky, E., Fisher, R., Lowry, D., Michel, S., Myhre, C., Platt, M., Allen, G., Bousquet, P., Brownlow, R., Cain, M., France, J., Hermansen, O., Hossaini, 
R., Jones, A., Levin, I., Manning, A., Myhre, G., Pyle, J., Vaughn, B., Warwick, N., and White, J.: Very Strong. Atmospheric Methane Growth in the 4 Years 2014-2017: Implications for the paris Agreement, Global Biogeochem. Cy., 33, 318-342, https://doi.org/10.1029/2018GB006009, 2019.

Orbe, C., Oman, L., Strahan, S., Waugh, D., Pawson, S., Takacs, L., and Molod, A.: Large-Scale Atmospheric Transport in GEOS Replay Simulations, J. Adv. Model. Earth Sy., 9, 2545-2560, https://doi.org/10.1002/2017MS001053, 2017.

Patra, P. K., Houweling, S., Krol, M., Bousquet, P., Belikov, D., Bergmann, D., Bian, H., Cameron-Smith, P., Chipperfield, M. P., Corbin, K., Fortems-Cheiney, A., Fraser, A., Gloor, E., Hess, P., Ito, A., Kawa, S. R., Law, R. M., Loh, Z., Maksyutov, S., Meng, L., Palmer, P. I., Prinn, R. G., Rigby, M., Saito, R., and Wilson, C.: TransCom model simulations of $\mathrm{CH} 4$ and related species: linking transport, surface flux and chemical loss with $\mathrm{CH} 4$ variability in the troposphere and lower stratosphere, Atmos. Chem. Phys., 11, 12813-12837, https://doi.org/10.5194/acp-11-128132011, 2011.

Platt, U., Allan, W., and Lowe, D.: Hemispheric average $\mathrm{Cl}$ atom concentration from ${ }^{13} \mathrm{C} /{ }^{12} \mathrm{C}$ ratios in atmospheric methane, Atmos. Chem. Phys., 4, 2393-2399, https://doi.org/10.5194/acp-42393-2004, 2004.

Quay, P., King, S., Stutsman, J., Wilbur, D., Steele, L., Fung, I., Gammon, R., Brown, T., Farwell, G., Grootes, P., and Schmidt, F.: Carbon Isotopic Composition of Atmospheric $\mathrm{CH}_{4}$ : Fossil and Biomass Burning Source Strenghts, Global Biogeochem. Cy., 5, 25-47, https://doi.org/10.1029/91GB00003, 1991.

Rice, A. L., Butenhoff, C. L., Teama, D. G., Röger, F. H., Khalil, M. A. K., and Rasmussen, R. A.: Atmospheric methane isotopic record favors fossil sources flat in 1980s and 1990s with recent increase, P. Natl. Acad. Sci. USA, 113, 10791-10796, 2016.

Rigby, M., Prinn, R. G., Fraser, P. J., Simmonds, P. G., Langenfelds, R. L., Huang, J., Cunnold, D. M., Steele, L. P., Krummel, P. B., Weiss, R. F., O'Doherty, S., Salameh, P. K., Wang, H. J., Harth, C. M., Mühle, J., and Porter, L. W.: Renewed growth of atmospheric methane, Geophys. Res. Lett., 35, L22805, https://doi.org/10.1029/2008GL036037, 2008.

Rigby, M., Montzka, S. A., Prinn, R. G., White, J. W., Young, D., O’Doherty, S., Lunt, M. F., Ganesan, A. L., Manning, A. J., and Simmonds, P. G.: Role of atmospheric oxidation in recent methane growth, P. Natl. Acad. Sci. USA, 114, 5373-5377, 2017.

Rotman, D., Tannahill, J., Kinnison, D., Connell, P., Bergmann, D., Proctor, D., Rodriguez, J., Lin, S., Rood, R., Prather, M., Rasch, P., Considine, D., Ramaroson, R., and Kawa, S.: Global Modeling Initiative assessment model: Model description, integration, and testing of the transport shell, J. Geophys. Res.-Atmos., 106, 1669-1691, https://doi.org/10.1029/2000JD900463, 2001.

Saueressig, G., Bergamaschi, P., Crowley, J., Fischer, H., and Harris, G.: Carbon Kinetic Isotope Effect in the Reaction of $\mathrm{CH}_{4}$ with $\mathrm{Cl}$ Atoms, Geophys. Res. Lett., 22, 1225-1228, https://doi.org/10.1029/95GL00881, 1995.

Saueressig, G., Crowley, J. N., Bergamaschi, P., Brühl, C., Brenninkmeijer, C. A. M., and Fischer, H.: Carbon 13 and $\mathrm{D}$ kinetic isotope effects in the reactions of $\mathrm{CH}_{4}$ with $\mathrm{O}\left({ }^{1} \mathrm{D}\right)$ and $\mathrm{OH}$ : New laboratory measurements and their implications for the isotopic composition of stratospheric methane, J. Geophys. Res.-Atmos., 106, 23127-23138, https://doi.org/10.1029/2000JD000120, 2001.
Saunois, M., Bousquet, P., Poulter, B., Peregon, A., Ciais, P., Canadell, J. G., Dlugokencky, E. J., Etiope, G., Bastviken, D., Houweling, S., Janssens-Maenhout, G., Tubiello, F. N., Castaldi, S., Jackson, R. B., Alexe, M., Arora, V. K., Beerling, D. J., Bergamaschi, P., Blake, D. R., Brailsford, G., Brovkin, V., Bruhwiler, L., Crevoisier, C., Crill, P., Covey, K., Curry, C., Frankenberg, C., Gedney, N., Höglund-Isaksson, L., Ishizawa, M., Ito, A., Joos, F., Kim, H.-S., Kleinen, T., Krummel, P., Lamarque, J.-F., Langenfelds, R., Locatelli, R., Machida, T., Maksyutov, S., McDonald, K. C., Marshall, J., Melton, J. R., Morino, I., Naik, V., O’Doherty, S., Parmentier, F.-J. W., Patra, P. K., Peng, C., Peng, S., Peters, G. P., Pison, I., Prigent, C., Prinn, R., Ramonet, M., Riley, W. J., Saito, M., Santini, M., Schroeder, R., Simpson, I. J., Spahni, R., Steele, P., Takizawa, A., Thornton, B. F., Tian, H., Tohjima, Y., Viovy, N., Voulgarakis, A., van Weele, M., van der Werf, G. R., Weiss, R., Wiedinmyer, C., Wilton, D. J., Wiltshire, A., Worthy, D., Wunch, D., Xu, X., Yoshida, Y., Zhang, B., Zhang, Z., and Zhu, Q.: The global methane budget 2000-2012, Earth Syst. Sci. Data, 8, 697-751, https://doi.org/10.5194/essd-8-697-2016, 2016.

Saunois, M., Bousquet, P., Poulter, B., Peregon, A., Ciais, P., Canadell, J. G., Dlugokencky, E. J., Etiope, G., Bastviken, D., Houweling, S., Janssens-Maenhout, G., Tubiello, F. N., Castaldi, S., Jackson, R. B., Alexe, M., Arora, V. K., Beerling, D. J., Bergamaschi, P., Blake, D. R., Brailsford, G., Bruhwiler, L., Crevoisier, C., Crill, P., Covey, K., Frankenberg, C., Gedney, N., HöglundIsaksson, L., Ishizawa, M., Ito, A., Joos, F., Kim, H.-S., Kleinen, T., Krummel, P., Lamarque, J.-F., Langenfelds, R., Locatelli, R., Machida, T., Maksyutov, S., Melton, J. R., Morino, I., Naik, V., O'Doherty, S., Parmentier, F.-J. W., Patra, P. K., Peng, C., Peng, S., Peters, G. P., Pison, I., Prinn, R., Ramonet, M., Riley, W. J., Saito, M., Santini, M., Schroeder, R., Simpson, I. J., Spahni, R., Takizawa, A., Thornton, B. F., Tian, H., Tohjima, Y., Viovy, N., Voulgarakis, A., Weiss, R., Wilton, D. J., Wiltshire, A., Worthy, D., Wunch, D., Xu, X., Yoshida, Y., Zhang, B., Zhang, Z., and Zhu, Q.: Variability and quasi-decadal changes in the methane budget over the period 2000-2012, Atmos. Chem. Phys., 17, 11135-11161, https://doi.org/10.5194/acp-17-111352017, 2017.

Schaefer, H., Fletcher, S. E. M., Veidt, C., Lassey, K. R., Brailsford, G. W., Bromley, T. M., Dlugokencky, E. J., Michel, S. E., Miller, J. B., Levin, I., Lowe, D. C., Martin, R. J., Vaughn, B. H., and White, J. W. C.: A 21st-century shift from fossil-fuel to biogenic methane emissions indicated by ${ }^{13} \mathrm{CH}_{4}$, Science, 352 , 80-84, https://doi.org/10.1126/science.aad2705, 2016.

Schwietzke, S., Sherwood, O., Ruhwiler, L., Miller, J., Etiope, G., Dlugokencky, E., Michel, S., Arling, V., Vaughn, B., White, J., and Tans, P.: Upward revision of global fossil fuel methane emissions based on isotope database, Nature, 538, 88-91, https://doi.org/10.1038/nature19797, 2016.

Sherwen, T., Schmidt, J. A., Evans, M. J., Carpenter, L. J., Großmann, K., Eastham, S. D., Jacob, D. J., Dix, B., Koenig, T. K., Sinreich, R., Ortega, I., Volkamer, R., Saiz-Lopez, A., PradosRoman, C., Mahajan, A. S., and Ordóñez, C.: Global impacts of tropospheric halogens $(\mathrm{Cl}, \mathrm{Br}, \mathrm{I})$ on oxidants and composition in GEOS-Chem, Atmos. Chem. Phys., 16, 12239-12271, https://doi.org/10.5194/acp-16-12239-2016, 2016.

Sherwood, O. A., Schwietzke, S., Arling, V. A., and Etiope, G.: Global Inventory of Gas Geochemistry Data from Fossil 
Fuel, Microbial and Burning Sources, version 2017, Earth Syst. Sci. Data, 9, 639-656, https://doi.org/10.5194/essd-9-639-2017, 2017.

Spivakovsky, C. M., Logan, J. A., Montzka, S. A., Balkanski, Y. J., Foreman-Fowler, M., Jones, D. B. A., Horowitz, L. W., Fusco, A. C., Brenninkmeijer, C. A. M., Prather, M. J., Wofsy, S. C., and McElroy, M. B.: Three-dimensional climatological distribution of tropospheric OH: Update and evaluation, J. Geophys. Res.Atmos., 105, 8931-8980, https://doi.org/10.1029/1999jd901006, 2000.

Strahan, S. E., Duncan, B. N., and Hoor, P.: Observationally derived transport diagnostics for the lowermost stratosphere and their application to the GMI chemistry and transport model, Atmos. Chem. Phys., 7, 2435-2445, https://doi.org/10.5194/acp-72435-2007, 2007.

Strahan, S. E., Douglass, A. R., and Newman, P. A.: The contributions of chemistry and transport to low arctic ozone in March 2011 derived from Aura MLS observations, J. Geophys. Res.Atmos., 118, 1563-1576, 2013.

Strode, S. A., Duncan, B. N., Yegorova, E. A., Kouatchou, J., Ziemke, J. R., and Douglass, A. R.: Implications of carbon monoxide bias for methane lifetime and atmospheric composition in chemistry climate models, Atmos. Chem. Phys., 15, 11789-11805, https://doi.org/10.5194/acp-15-11789-2015, 2015.

Tans, P.: A note on isotopic ratios and the global atmospheric methane budget, Global Biogeochem. Cy., 11, 77-81, https://doi.org/10.1029/96GB03940, 1997.

Thompson, R., Nisbet, E., Pisso, I., Stohl, A., Blake, D., Dlugokencky, E., Helmig, D., and White, J.: Variability in Atmospheric Methane From Fossil Fuel and Microbial Sources Over the Last Three Decades, Geophys. Res. Lett., 45, 11499-11508, https://doi.org/10.1029/2018GL078127, 2018.

Thompson, R. L., Stohl, A., Zhou, L. X., Dlugokencky, E., Fukuyama, Y., Tohjima, Y., Kim, S. Y., Lee, H., Nisbet, E. G., and Fisher, R. E.: Methane emissions in East Asia for 2000-2011 estimated using an atmospheric Bayesian inversion, J. Geophys. Res.-Atmos., 120, 4352-4369, 2015.

Turner, A., Jacob, D., Benmergui, J., Wofsy, S., Maasakkers, J., Butz, A., Hasekamp, O., and Biraud, S.: A large increase in US methane emissions over the past decade inferred from satellite data and surface observations, Geophys. Res. Lett., 43, 2218 2224, https://doi.org/10.1002/2016GL067987, 2016.
Turner, A. J., Frankenberg, C., Wennberg, P. O., and Jacob, D. $\mathrm{J}$.: Ambiguity in the causes for decadal trends in atmospheric methane and hydroxyl, P. Natl. Acad. Sci. USA, 114, 5367-5372, 2017.

Tyler, S. C., Crill, P. M., and Brailsford, G. W.: ${ }^{13} \mathrm{C}^{12} \mathrm{C}$ Fractionation of methane during oxidation in a temperate forested soil, Geochim. Cosmochim. Ac., 58, 1625-1633, https://doi.org/10.1016/0016-7037(94)90564-9, 1994.

Wang, J. S., McElroy, M. B., Spivakovsky, C. M., and Jones, D. B. A.: On the contribution of anthropogenic $\mathrm{Cl}$ to the increase in $\delta^{13} \mathrm{C}$ of atmospheric methane, Global Biogeochem. Cy., 16, 1047, https://doi.org/10.1029/2001GB001572, 2002.

Wang, X., Jacob, D. J., Eastham, S. D., Sulprizio, M. P., Zhu, L., Chen, Q., Alexander, B., Sherwen, T., Evans, M. J., Lee, B. H., Haskins, J. D., Lopez-Hilfiker, F. D., Thornton, J. A., Huey, G. L., and Liao, H.: The role of chlorine in global tropospheric chemistry, Atmos. Chem. Phys., 19, 3981-4003, https://doi.org/10.5194/acp-19-3981-2019, 2019.

Waugh, D., Crotwell, A., Dlugokencky, E., Dutton, G., Elkins, J., Hall, B., Hintsa, E., Hurst, D., Montzka, S., Mondeel, D. Moore, F., Nance, J., Ray, E., Steenrod, S., Strahan, S., and Sweeney, C.: Tropospheric SF6: Age of air from the Northern Hemisphere midlatitude surface, J. Geophys. Res.-Atmos., 118, 11429-11441, https://doi.org/10.1002/jgrd.50848, 2013.

White, J. W. C., Vaughn, B. H., and Michel, S. E.: University of Colorado, Institute of Arctic and Alpine Research (INSTAAR), Stable Isotopic Composition of Atmospheric Methane $\left({ }^{13} \mathrm{C}\right)$ from the NOAA ESRL Carbon Cycle Cooperative Global Air Sampling Network, 1998-2017, Version: 2018-09-24, available at: ftp://aftp.cmdl.noaa.gov/data/trace_gases/ch4c13/flask/ (last access: 30 January 2019), 2018.

Worden, J. R., Bloom, A. A., Pandey, S., Jiang, Z., Worden, H. M., Walker, T. W., Houweling, S., and Röckmann, T.: Reduced biomass burning emissions reconcile conflicting estimates of the post-2006 atmospheric methane budget, Nat. Commun., 8, 2227, https://doi.org/10.1038/s41467-017-02246-0, 2017.

Zhang, Q.-L. and Li, W.-J.: A Calibrated Measurement of the Atomic Weight of Carbon, Chinese Sci. Bull., 35, 290-296, 1990. 